\title{
A critical review of producers of small lactone mycotoxins: patulin, penicillic acid and moniliformin
}

Frisvad, J.C.

Published in:

World Mycotoxin Journal

Link to article, DOI:

10.3920/WMJ2017.2294

Publication date:

2018

Document Version

Publisher's PDF, also known as Version of record

Link back to DTU Orbit

Citation (APA):

Frisvad, J. C. (2018). A critical review of producers of small lactone mycotoxins: patulin, penicillic acid and moniliformin. World Mycotoxin Journal, 11(1), 73-100. https://doi.org/10.3920/WMJ2017.2294

\section{General rights}

Copyright and moral rights for the publications made accessible in the public portal are retained by the authors and/or other copyright owners and it is a condition of accessing publications that users recognise and abide by the legal requirements associated with these rights.

- Users may download and print one copy of any publication from the public portal for the purpose of private study or research.

- You may not further distribute the material or use it for any profit-making activity or commercial gain

- You may freely distribute the URL identifying the publication in the public portal

If you believe that this document breaches copyright please contact us providing details, and we will remove access to the work immediately and investigate your claim 


\title{
A critical review of producers of small lactone mycotoxins: patulin, penicillic acid and moniliformin
}

\author{
J.C. Frisvad \\ Department of Biotechnology and Biomedicine, Technical University of Denmark, Søltofts Plads Building 221, 2800 Kgs. \\ Lyngby, Denmark; jcf@bio.dtu.dk
}

Received: 19 december 2017 / Accepted: 26 January 2018

(c) 2018 Wageningen Academic Publishers

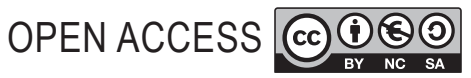

REVIEW ARTICLE

\begin{abstract}
A very large number of filamentous fungi has been reported to produce the small lactone mycotoxins patulin, penicillic acid and moniliformin. Among the 167 reported fungal producers of patulin, only production by 29 species could be confirmed. Patulin is produced by 3 Aspergillus species, 3 Paecilomyces species, 22 Penicillium species from 7 sections of Penicillium, and one Xylaria species. Among 101 reported producers of penicillic acid, 48 species could produce this mycotoxin. Penicillic acid is produced by 23 species in section Aspergillus subgenus Circumdati section Circumdati, by Malbranchea aurantiaca and by 24 Penicillium species from 9 sections in Penicillium and one species that does not actually belong to Penicillium (P. megasporum). Among 40 reported producers of moniliformin, five species have been regarded as doubtful producers of this mycotoxin or are now regarded as taxonomic synonyms. Moniliformin is produced by 34 Fusarium species and one Penicillium species. All the accepted producers of patulin, penicillic acid and moniliformin were revised according to the new one fungus - one name nomenclatural system, and the most recently accepted taxonomy of the species.
\end{abstract}

Keywords: patulin, penicillic acid, moniliformin, terrestric acid, Penicillium, Aspergillus, Fusarium

\section{Introduction}

Small toxic lactones, especially patulin, penicillic acid and moniliformin are recognised mycotoxins (Bemi, 2004; Ciegler et al., 1971; Gaucher, 1979; McKinley and Carlton, 1991; Moake et al., 2005; Puel et al., 2010; Schütt et al., 1998; Scott, 1974; Wilson, 1976), even though only patulin is under regulation (EC, 2003). They share some properties apart from being toxic and having some structural similarities. They are all polar, acidic, secondary metabolites often produced in large amounts in foods and feeds (Ciegler et al., 1971), even though they differ in the niches their producers occupy: patulin is often associated with fruits and penicillic acid and moniliformin with cereals. Patulin and penicillic acid were early on recognised as effective antibiotics (Chain et al., 1942; Florey et al., 1949; Korzybski et al., 1967; Oxford et al., 1942; Singh, 1967), and have later been show also to inhibit quorum sensing in bacteria (Rasmussen et al., 2005). Patulin and penicillic acid also share a specific reaction with the sulfhydryl- containing amino acids cysteine and gluthatione (Larsen and Olson, 1992; Morgavi et al., 2003). While this may help inactivating these mycotoxins in foods containing cysteine and gluthatione, those data indicate that part of the toxic effect of the small lactones is the binding of S-containing amino acids in proteins.

Apart from being an effective antibiotic, patulin can also produce petit mutants in Saccharomyces cerevisiae (Mayer and Legator, 1969). Patulin can act as a phytotoxin (Ellis et al., 1977; Florey et al., 1949; Ismail and Papenbrock, 2015; Korzybski et al., 1967; Scott, 1974) and is active against pathogenic fungi (Gilliver, 1946; Herrick, 1945; Sanders, 1946). Patulin was initially suggested for treatment of common cold (Birkinshaw et al., 1943; Gye, 1943), as it is anti-viral (Detroy and Still, 1975) in addition to being antibacterial, but the trials on humans were quickly dropped because of the toxicity of patulin. 
Patulin has been reported to be acutely toxic (Ciegler, 1977; Devaraj et al., 1986; Drusch and Ragab, 2003; Engel and Teuber, 1984; Escoula et al., 1977; Fung and Clark, 2004; Hayes et al., 1979; Hopkins, 1993; McKinley and Carlton, 1980a,b; McKinley et al., 1982; Wouters and Speijers, 1996), teratogenic (Ciegler et al., 1976; Vesely and Vesela, 1991), cardiotoxic (Vesely and Vesela, 1991), it influences the colonic epithelial permeability (Maidana et al., 2016; Mohan et al., 2012), and it is immunotoxic (Bourdiol et al., 1990; Escoula et al., 1988; Paucod et al., 1990; Sharma, 1993). Patulin is first of all found in pomaceous foods like apples and pears, but also in other fruits (Beretta et al., 2000; Jackson and Dombrinck-Kurtzman, 2006; Yang et al., 2014).

Penicillic acid was first reported by Alsberg and Black (1913) in an examination of fungal growth in maize and potential fungal involvement in pellagra. Its structure was elucidated by Birkinshaw et al. (1936) and its antibacterial effect against Gram positive and Gram negative bacteria was first reported by Oxford in 1942, Oxford et al. in 1942 and Geiger and Conn in 1945, as reviewed by Korzybski et al. (1967). Later the antibiotic effect of penicillic acid has also been reported by Ezzat et al. (2007). Penicillic acid is also very inhibitory towards Phytophthora species (Kang and Kim, 2004). Furthermore, penicillic acid is phytotoxic (Ismaiel and Papenbrock, 2015).

Penicillic acid has been shown to be acutely toxic to poultry, mice, rats and rabbits (Cole and Cox, 1981). Furthermore, it dilates blood vessels and possesses antidiuretic properties (Murnaghan, 1946). Penicillic acid has been involved in broiler chicken mycotoxicosis (Ghadevaru, 2013; Samadha and Balachandran, 2008; Sarmadha et al., 2008) but gingerol has been shown to alleviate the toxic effects of penicillic acid (Pazhavinel et al., 2015). Penicillic acid is cytotoxic (Grabsch et al., 2006), hepatotoxic (Chan and Hayes, 1981), and has been claimed to be carcinogenic and cardiotoxic (Dickens and Jones, 1961, 1963, 1965; Vesely and Vesela, 1991), and a sodium, potassium and calcium channel blocker in frog hearts (Pandiyan et al., 1990). It is also toxic to rat alveolar macrophages (Sorenson and Simpson, 1986).

Ochratoxin A and penicillic acid show synergistic toxicity on bovine macrophage cell lines (Oh et al., 2015), in chickens (Kubena et al., 1984; Micco et al., 1989), in the corn ear worm and the fall armyworm (Dowd, 1989). The two toxins together also increase degeneration in kidney proximal tubules (Klarić et al., 2013; Stoev, 2013; Stoev and Denev, 2013). The synergistic worm toxicity of penicillic acid and ochratoxin $\mathrm{A}$ is interesting as the fungi producing these combinations of toxins are often growing in corn and other cereals (Lund and Frisvad, 1994; Visagie et al., 2014a). Other studies have only shown an additive toxic effect on porcine lymphocytes of ochratoxin A and penicillic acid (Bernhoft et al., 2004; Stoev et al., 1999). These two mycotoxins are often co-occurring as Aspergillus from section Circumdati produce penicillic acid and ochratoxin simultaneously in most species from that section (Visagie et al., 2014a). Furthermore, species from Penicillium section Fasciculata series Viridicata and Verrucosa co-occur in cereals (Lund and Frisvad, 1995), and thus penicillic acid and ochratoxin A are also both found often in contaminated cereals.

It has been suggested that ochratoxin A and penicillic acid may both be involved in Balkan Endemic Nephropathy (Stoev, 2017; Stoev et al., 2001). Penicillium polonicum and Penicillium aurantiogriseum, both producing penicillic acid, verrucosidin and nephrotoxic glycopeptides, are often found in the Balkan countries, but Penicillium verrucosum, the main ochratoxin A producing Penicillium species in cereals, is found less often (MacGeorge and Mantle, 1990; Mantle, 1994; Mantle et al., 2010; Miljkovic et al., 2003; Stoev et al., 2010; Yeulet et al., 1988). Penicillic acid is mostly found in cereals (Bokhari and Flannigan, 1996; Chełkowski and Golinski, 1983; Chełkowski et al., 1983, 1987; Kurtzman and Ciegler, 1970; Szebiotko et al., 1981; Tangni and Pussemier, 2007) and some other products like cassava (Wareing et al., 2001).

Terrestric acid is rather closely related to penicillic acid, and is produced by $P$. aurantiogriseum, Penicillium crustosum (= Penicillium terrestre), Penicillium hirsutum, Penicillium hordei, Penicillium radicicola, Penicillium tricolor, Penicillium tulipae, Penicillium venetum and Magnaporte grisea $=$ Pyricularia oryzae (Birkinshaw and Raistrick, 1936; Frisvad and Samson, 2004; Frisvad et al., 1994, 2004; Lund and Frisvad, 1994; Overy and Frisvad, 2003; Overy et al., 2005; Sonjak et al., 2005; Yu et al., 2010). Production of terrestric acid by Penicillium griseoroseum (Da Silva et al., 2013), and Penicillium viridicatum (Birkinshaw and Samant, 1960) could not be confirmed (Frisvad and Samson, 2004), other metabolites produced by these organisms indicate they were in fact $P$. crustosum (Frisvad et al., 2014). Terrestric acid has also been reported from $P$. hirsutum var. albocoremium (Frisvad and Filtenborg, 1989), but this taxon was later subdivided in Penicillium albocoremium, $P$. radicicola and $P$. tulipae. Only the last two species produce terrestric acid (Overy and Frisvad, 2003; Overy et al., 2005). This small acidic lactone is also phytotoxic (Nukina, 1988) and cardiotoxic (Giarman, 1948, 1949), thus resembling penicillic acid in some of its bioactivities. $P$. aurantiogriseum, $P$. radicicola and $P$. tulipae can produce both penicillic acid and terrestric acid (Frisvad et al., 2004; Overy and Frisvad, 2003; Overy et al., 2005).

Like penicillic acid, moniliformin has also been found in cereals and other plant products (Herrare et al., 2017; Kovalsky et al., 2016; Neme and Mohammed, 2017; Uhlig et al., 2004). An important fact is that while moniliformin is mostly produced by important field-fungi, such as Fusarium spp., penicillic acid is produced by storage fungi only. Moniliformin has not been reported as an antibiotic or 
quorum sensing inhibitor in bacteria (Bacon et al., 2017), but moniliformin is acutely toxic to poultry (Burmeister et al., 1979; Cole et al., 1973; Sharma et al., 2008) and rats (Chen et al., 1990; Jonsson et al., 2013, 2015; Thiel, 1978), in the latter study indicating a severe impact on the immune system. It inhibits several enzymes important in metabolism (Burka et al., 1982). It is cardiotoxic and effects mammalian smooth muscle (Kamyar et al., 2006; Peltonen et al., 2010). Moniliformin is also phytotoxic and has plant growthregulating properties (Cole et al., 1973).

There is one example of co-production of penicillic acid and patulin by Penicillium roqueforti (Olivigni and Bullerman, 1977, 1978), but the producing organism was reidentified to Penicillium carneum later (Boysen et al., 1996; Frisvad and Samson, 2004; Frisvad et al., 2004). Penicillium melanoconidium has been reported to produce moniliformin and penicillic acid (Hallas-Møller et al., 2016), but no species has been reported to produce patulin and moniliformin concomitantly.

It was the aim of this review to revise the lists of producers of patulin, penicillic acid and moniliformin according to the most recent taxonomic treatments of the genera Aspergillus (Chen et al., 2016a,b, 2017; Frisvad, 2015; Frisvad and Larsen, 2015; Hubka et al., 2015, 2016; Jurjevics et al., 2015; Kocsubé et al., 2016; Samson et al., 2011a,b, 2014, 2017; Sklenář et al., 2017; Varga et al., 2007a,b, 2011a,b; Visagie et al., 2014a, 2017), Penicillium (Frisvad and Samson, 2004; Houbraken et al., 2016; Visagie et al., 2014b) and Fusarium (Aoki et al., 2014; Burgess, 2014; Gerlach and Nirenberg, 1982; Lesley and Summerell, 2016; Nelson et al., 1983), as correct species-mycotoxin relations are important for prevention of mycotoxin formation in foods, feeds and biotechnological products.

\section{Criteria for accepting a species as a producer of one or more small toxic lactones}

Confirmation of mycotoxin production by a species of a filamentous fungus requires that both the fungus and the mycotoxin are correctly identified. Furthermore, it should be verified that the fungus examined is a pure culture. Also the fungal strain producing the mycotoxins should be available to the scientific community. In several cases the producing fungi were never accessioned in a culture collection, so the experiments could not be repeated and the identity of the fungal strain could not be verified or validated. If the mycotoxinogenic isolate was identified using a polyphasic approach, using a combination of morphological, physiological, chemical, and molecular features, the identifications are often correct. Molecular identification should be based on sequences of several genes, because ITS sequences are not always sufficient for correct identification at the species level (Raja et al., 2017; Seifert et al., 2007). Several independent reports of production of a particular mycotoxin by a particular fungal species adds to the credulity of a species-mycotoxin connection (Frisvad, 1989; Frisvad and Samson, 2004). Often production of a particular secondary metabolite is taxonomically restricted to rather few, often phylogenetically related species, so unexpected mycotoxin formation from phylogenetically unrelated species to known producers should be confirmed with special care. It should be noted that some groups of species have been revised several times, so a name that was valid earlier now may just be a synonym or a rejected name. Furthermore, the one fungus - one name system introduced in 2011 has caused a lot of changes. For example species earlier called Eurotium, Neosartorya, Emericella are now all called Aspergillus (Samson et al., 2014) and Fusarium is the preferred name for species formerly allocated to Gibberella (Geiser et al., 2013). It also adds to the credulity of the reported specific mycotoxin production, if the toxin has been detected in a large number of isolates in the species examined.

It should also be documented that the growth medium used for mycotoxin production does not contain the mycotoxin already. Often secondary metabolites are accumulated, so repeated reporting of trace amounts of mycotoxins on media otherwise suited for production may indicate that the mycotoxin was already present in the growth medium. This is most important for media based on cereals, as these can contain trace amounts of mycotoxins if field or storage fungi have grown in such substrates. It is in general recommended to analyse control samples for mycotoxins and use chemically defined media in a confirmation of mycotoxin production, if unexpected results have been obtained using plant based media.

Chemical analysis, for example using HPLC methods for separation and combined with sensitive detection methods will also inherently carry the risk of carry over of mycotoxins, so here proper controls are also needed. Chromatographic and spectrometric verification of the identity of the mycotoxin is needed to guard against false positives. If the retention times in several chromatographic systems is equal to the retention time of an authentic chemical standard, this is valuable confirmation of identity, but on top of that high resolution mass spectra (MS) and/ or UV spectra, as compared to an authentic standard are necessary to confirm identity. It is recommended to have at least 3 different independent confirmations of identity, and one of them should preferably be high resolution mass spectrometry (identical mass ions and relevant adducts as compared to a standard) and even the same mass fragmentation pattern as an authentic standard. Occasionally chemical identity is confirmed by nuclear magnetic resonance (NMR) characterisation, circular dichroism (CD) spectra, fourier transform infrared (FTIR) spectra, etc., especially the first time a secondary metabolite is structure elucidated and isolated from a 
particular species. NMR, CD and FTIR can also be used for a very solid confirmation of identity. Other types of data, for example detection of biosynthetic precursors, and discovery of the gene cluster or part of it for the particular mycotoxin under scrutiny adds further data to support a mycotoxin-fungal species connection. The criteria for accepting a fungus as a producer of patulin, penicillic acid or moniliformin include the following: production has been reported several times and in several different strains (more than one time and from different research groups), fungal identification has been documented, the fungal producing strains are available for the scientific community, and at least three chromatographic and spectrometric kinds of confirmatory data have been provided. If, in addition, parts of the gene cluster for the mycotoxins have been found, NMR data for the mycotoxin have been made available, or the biosynthesis has been confirmed, for example by detecting biosynthetic precursors, the documentation for such relationships is of course even stronger.

\section{Patulin and producing organisms}

The biosynthesis of patulin, starting from 6-methyl salicylic acid is well known (Barad et al., 2016c; Birch et al., 1955; Bu'Lock and Ryan 1958; Dimroth et al., 1976; Forrester and Gaucher, 1972a,b; Priest, 1989; Puel et al., 2010; Scott et al., 1971, 1972; Sekiguchi, 1983; Sekiguchi and Gaucher, 1978; Tanenbaum and Bassett, 1959), and the gene cluster for patulin has been found in different producing filamentous fungi (Ballester et al., 2015; Barad et al., 2016c; Dombrink-Kurtzman, 2007; Li et al., 2015; Nielsen et al., 2017; Puel et al., 2010; Snini et al., 2014; Tannous et al., 2014). The role of patulin itself in the fruit infection process has not been fully elucidated (Barad et al., 2016a,b), but it has been suggested that accumulation of both gluconic acid and patulin (Barad et al., 2012, 2014, 2016a; Snini et al., 2015) will make Penicillium expansum a more aggressive post-harvest pathogen. However, patulin may also be important for P.expansum itself in the competition with other microorganisms thriving in the fruit. It should be noted that the two other apple pathogenic Penicillia, Penicillium solitum and P. crustosum, do not produce patulin (Frisvad and Samson, 2004; Sanderson and Spotts, 1995), questioning the importance of patulin in the infection process.

The main end-product is patulin itself, but other related toxins are known, such as neopatulin, isopatulin, desoxypatulinic acid, ascladiol, longianone and pintulin (Appell et al., 2009; Bennett et al., 1990, 1991; Ghisalberti et al., 2000; Lykakis et al., 2009; Mikami et al., 1996; Scott et al., 1972; Sekiguchi et al., 1979).

Many strains producing patulin have been genome sequenced, including P. expansum (Ballester et al., 2015; Barad et al., 2016c; Julca et al., 2015; Yin et al., 2017; Yu et al., 2014), P. griseofulvum (Banani et al., 2016), Penicillium antarcticum, P. carneum, Penicillium paneum, and Penicillium vulpinum (Nielsen et al., 2017). A comparison of the gene clusters for patulin production in the different species shows they are quite similar, and that $P$. roquefort $i$ has part of the gene cluster needed to produce patulin, but lacks essential genes, making it unable to produce patulin (Nielsen et al., 2017).

Patulin has been reported from 166 different species, varieties and chemotypes (Table 1), but the documentation for some of all these producers is occasionally doubtful. In many of the publications, the original producers reported are not available to the scientific community. For example, in the papers by Steiman et al. (1989), Okeke et al. (1993), and Oh et al. (1998), accession numbers of the fungi examined are not available, and thus it is not possible to verify the identity of the producers. In the paper by Okeke et al. (1993) some very efficient producers of patulin are reported, often known producers of patulin, such as $P$. expansum, while most of the trace producers of patulin are fungi not expected to produce patulin, such as Trichothecium roseum. It has been a general experience that when a fungus can produce patulin, it will always accumulate large amounts of the toxin, never a small trace of a toxin (Frisvad, personal observations). It is tempting to speculate that the detection of patulin in unexpected species was caused by carry over in the HPLC chromatographic system or because of contamination with efficient patulin producers. Patulin has been found in sections Canescentia, Formosana, Gladioli, Osmophila, Penicillium, Ramosa and Robsamsonia in Penicillium, but only in section Clavati in Aspergillus.

Patulin has the formula $\mathrm{C}_{7} \mathrm{H}_{6} \mathrm{O}_{4}$, and a molecular mass of 154, and a monoisotopic mass of 154.026. Searching in the Microbial secondary metabolite database AntiBase with approximately 40,000 natural products, 95 secondary metabolites have the molecular mass of 154, while 13 fungal secondary metabolites had a monoisotopic mass of 154.026, including members of the patulin biosynthetic pathway patulin, isopatulin, neopatulin, gentisic acid, longianone and (-)-phyllostine. However, other secondary metabolites, such as terreic acid and terremutin also have the monoisotopic mass of 154.026. This may be the reason Aspergillus terreus was reported to produce patulin (Draughon and Ayers, 1980; El-Shanawany et al., 2005; Escoula, 1974; Girisham and Reddy, 1986a,b; Giridhar and Reddy, 1998; Kent and Heatley, 1945; Reddy and Reddy, 1984, 1988), while it was probably terreic acid that was detected. Given several references on patulin production by $A$. terreus, it cannot be excluded that this species, or one of the closely related species, can produce it. Obviously for such small molecules, mass spectrometric (MS) verification is of value, but has to be combined with other data, such as an UV spectrum identical to that of patulin and retention time verification, 
Table 1. Filamentous fungi claimed to produce patulin (also called clavacin, clavatin, claviformin, expansin and penicidin).

\begin{tabular}{|c|c|c|}
\hline Fungal species & References & Synonymised species \\
\hline Acremonium implicatum & Ismaiel et al., 2016 & \\
\hline Acremonium persicinum & Okeke et al., 1993 & \\
\hline Acremonium sclerotigenum & Okeke et al., 1993 & \\
\hline Acremonium zeae & Steiman et al., 1989 & \\
\hline Alternaria alternata & Drusch and Ragab, 2003; Leidou et al., 2001; Steiman et al., 1989 & \\
\hline Alternaria papaveris & Steiman et al., 1989 & \\
\hline Alternaria tenuissima & Okeke et al., 1993 & \\
\hline Ascochyta imperfecta & Steiman et al., 1989 & \\
\hline Aspergillus amstelodami & Steiman et al., 1989 & \\
\hline Aspergillus candidus & Frank, 1977 & \\
\hline Aspergillus clavatus & $\begin{array}{l}\text { Bergel et al., 1943, 1944; Diaz and Flannigan, 1997; Escoula, 1974; Lopez-Varga et al., } \\
\text { 2007; Paterson, } 2004 \text { (IDH gene); Umezawa et al., 1947; Wiesner, } 1942\end{array}$ & \\
\hline Aspergillus echinulatus & Steiman et al., 1989 & \\
\hline Aspergillus flavus & Luque et al., 2011 & \\
\hline Aspergillus fumigatus & Steiman et al., 1989 & \\
\hline Aspergillus giganteus & Florey et al., 1944; Okeke et al., 1993; Paterson, 2004 (IDH gene); Varga et al., 2007a & \\
\hline Aspergillus longivesica & Varga et al., 2007a & \\
\hline Aspergillus manginii & Steiman et al., 1989 & \\
\hline Aspergillus ochraceus & Abu-Seidah, 2003 & \\
\hline Aspergillus oryzae & Chunmei et al., 2013; Luque et al., 2011 & \\
\hline Aspergillus parasiticus & Steiman et al., 1989 & \\
\hline Aspergillus petrakii & Okeke et al., 1993 & \\
\hline Aspergillus repens & Steiman et al., 1989 & \\
\hline Aspergillus sydowii & Chunmei et al., 2013 & \\
\hline Aspergillus tamarii & Luque et al., 2011 & \\
\hline Aspergillus terreus & $\begin{array}{l}\text { Couch and Gaucher, } 2004 \text { (MSA gene); El-Shanawany et al., 2005; Escoula, 1974; } \\
\text { Draughon and Ayers; 1980; Giridhar and Reddy, 1998; Girisham and Reddy, 1986a;b; } \\
\text { Kent and Heatley, 1945; Paterson, } 2004 \text { (IDH gene); Reddy and Reddy, 1984, 1988 }\end{array}$ & \\
\hline Aspergillus variecolor & Steiman et al., 1989 & \\
\hline Aspergillus versicolor & Steiman et al., 1989 & \\
\hline $\begin{array}{l}\text { Aureobasidium pullulans var. } \\
\text { pullulans }\end{array}$ & Steiman et al., 1989 & \\
\hline ‘Basidio 2’ & Steiman et al., 1989 & \\
\hline Botrytis allii & Steiman et al., 1989 & \\
\hline Byssochlamys fulva & $\begin{array}{l}\text { Escoula, 1974; Paterson, } 2004 \text { (IDH gene); Sant'Ana et al., 2010; } \\
\text { rejected by Puel et al., } 2007\end{array}$ & see Paecilomyces fulvus \\
\hline Byssochlamys nivea & $\begin{array}{l}\text { Escoula, 1974; Kis et al., 1969; Paterson, } 2004 \text { (IDH gene); Sant'Ana et al., 2010; } \\
\text { Scurti et al., } 1973\end{array}$ & see Paecilomyces niveus \\
\hline Calcarisporium arbuscula & Okeke et al., 1993; Steiman et al., 1989 & \\
\hline Chaetomium atrobrunneum & Okeke et al., 1993 & \\
\hline Chondrostereum purpureum & Okeke et al., 1993 & \\
\hline Chrysosporium pannorum & Steiman et al., 1989 & now Geomyces pannorum \\
\hline Cladobotryum varium & Steiman et al., 1989 & \\
\hline Cladobotryum verticillatum & Steiman et al., 1989 & \\
\hline Cladorrhinium sp. & Okeke et al., 1993; Steiman et al., 1989 & \\
\hline Colletotrichum musae & Steiman et al., 1989 & \\
\hline Coniothyrium sp. & Okeke et al., 1993 & \\
\hline Cunninghamella bainieri & Steiman et al., 1989 & \\
\hline Curvularia lunata & Steiman et al., 1989 & \\
\hline Cylindrocarpon cylindroides & Okeke et al., 1993 & \\
\hline Cylindrocarpon ianthotele & Okeke et al., 1993 & \\
\hline Cylindrocarpon olidum & Okeke et al., 1993 & \\
\hline
\end{tabular}


Table 1. Continued.

\begin{tabular}{|c|c|}
\hline Fungal species & References \\
\hline Dichotomomyces cejpii & Okeke et al., 1993 \\
\hline Emericella quadrilineata & Luque et al., 2011 \\
\hline Emericella rugulosa & Luque et al., 2011 \\
\hline Emericella variecolor & Luque et al., 2011 \\
\hline Eupenicillium brefeldianum & Okeke et al., 1993; Steiman et al., 1989 \\
\hline Eupenicillium javanicum & Okeke et al., 1993 \\
\hline Eupenicillium sp. 1 & Okeke et al., 1993 \\
\hline Eupenicillium sp. 2 & Okeke et al., 1993 \\
\hline Fusarium culmorum & Steiman et al., 1989 \\
\hline $\begin{array}{l}\text { Fusarium proliferatum var. } \\
\text { proliferatum }\end{array}$ & Steiman et al., 1989 \\
\hline Fusarium sp. & Xie et al., 2011 \\
\hline Gymnoascus sp. & Karow and Forster, 1944; Kuehn, 1958 \\
\hline Gymnoascus reesii & Okeke et al., 1993; Steiman et al., 1989 \\
\hline Mortierella bainieri & Steiman et al., 1989 \\
\hline Mucor hiemalis & Steiman et al., 1989 \\
\hline $\begin{array}{l}\text { Mucor racemosus var. } \\
\text { globosus }\end{array}$ & Steiman et al., 1989 \\
\hline Oidiodendron echinulatum & Steiman et al., 1989 \\
\hline Oidiodendron tenuissimum & Steiman et al., 1989 \\
\hline Paecilomyces lilacinus & Okeke et al., 1993; Steiman et al., 1989 \\
\hline Paecilomyces variotii & Escoula, 1975; Paterson, 2004 (IDH gene) \\
\hline Paecilomyces fulvus & renamed here from Byssochlamys fulva \\
\hline Paecilomyces niveus & renamed here from Byssochlamys nivea \\
\hline Paecilomyces saturatus & Samson et al., 2009 \\
\hline Penicillium antarcticum & Vansteelandt et al., 2012 \\
\hline Penicillium asperosporum & Moslem et al., 2011 \\
\hline Penicillium aurantiogriseum & $\begin{array}{l}\text { Luque et al., 2011; Moslem et al., 2010; Oh et al., 1998; Okeke et al., 1993; } \\
\text { Paterson, } 2004 \text { (IDH gene); Paterson et al., 2003; Steiman et al., } 1989\end{array}$ \\
\hline Penicillium brevicompactum & Paterson, 2004 (IDH gene); Paterson et al., 2003 \\
\hline Penicillium camemberti & Luque et al., 2011 \\
\hline Penicillium canescens & Steiman et al., 1989 \\
\hline Penicillium carneum & Boysen et al., 1996; Dombrinck-Kurtzman, 2007; Nielsen et al., 2006 \\
\hline Penicillium chrysogenum & Chunmei et al., 2013; Leistner and Pitt, 1977; Oh et al., 1998; Steiman et al., 1989 \\
\hline Penicillium citreonigrum & Steiman et al., 1989 \\
\hline Penicillium citrinum & El-Samawaty et al., 2013; Frank, 1977; Oh et al., 1998 \\
\hline Penicillium claviforme & $\begin{array}{l}\text { Afiyatullov et al., 2015; Bergel et al., 1943; Borkowska Opacka and Escoula, 1977; } \\
\text { Chain et al., 1942; Frisvad and Filtenborg, } 1983\end{array}$ \\
\hline Penicillium clavigerum & $\begin{array}{l}\text { Dombrinck-Kurtzman, 2007; Dombrink-Kurtzman and Blackburn, 2005; Svendsen and } \\
\text { Frisvad, } 1994\end{array}$ \\
\hline Penicillium commune & Luque et al., 2011; Oh et al., 1998 \\
\hline Penicillium compactum & Houbraken et al., 2016 \\
\hline Penicillium concentricum & $\begin{array}{l}\text { Dombrinck-Kurtzman, 2007; Frisvad and Samson, 2004; Frisvad et al., 2004; } \\
\text { Leistner and Eckardt, } 1979\end{array}$ \\
\hline Penicillium concentricum II & Frisvad and Filtenborg, 1983; Houbraken et al., 2016 \\
\hline Penicillium coprobium & $\begin{array}{l}\text { Frisvad and Filtenborg, 1989; Frisvad and Samson, 2004; Frisvad et al., 2004; } \\
\text { Dombrink-Kurtzman and Blackburn, 2005; Houbraken et al., } 2016\end{array}$ \\
\hline Penicillium corylophilum & Paterson, 2004 (IDH gene); Vismer et al., 1996 \\
\hline Penicillium crustosum & Northolt et al., 1978; Yun et al., 2006 \\
\hline Penicillium cyaneofulvum & Berestetskii et al., 1974 \\
\hline Penicillium cyaneum & Okeke et al., 1993 \\
\hline
\end{tabular}


Table 1. Continued.

\begin{tabular}{|c|c|c|}
\hline Fungal species & References & Synonymised species \\
\hline Penicillium cyclopium & Efimenko and Yakimov, 1960; Frank, 1972; 1977; Leistner and Pitt, 1977 & \\
\hline Penicillium dipodomyicola & $\begin{array}{l}\text { Dombrinck-Kurtzman, 2007; Frisvad and Samson, 2004; Frisvad et al., 1987, 2004; } \\
\text { Houbraken et al., 2016; Luque et al., } 2011\end{array}$ & \\
\hline Penicillium dipodomyis & Koteswara Rao et al., 2011 & \\
\hline Penicillium divergens & Barta and Mecir, 1948, & see $P$. glandicola \\
\hline Penicillium diversum & Okeke et al., 1993 & \\
\hline Penicillium duclaucxii & Okeke et al., 1993 & \\
\hline Penicillium echinulatum & Okeke et al., 1993 & \\
\hline Penicillium equinum & Burton, 1949; Burton and Pausacker, 1947 & see $P$. expansum \\
\hline Penicillium expansum & $\begin{array}{l}\text { Luijk, 1938; Andersen et al., 2004; Anslow et al., 1943; Borkowska Opacka and } \\
\text { Escoula, 1977; Casquete et al., 2017; Chunmei et al., 2013; Dombrinck-Kurtzman, } \\
\text { 2007; Dombrink-Kurtzman and Blackburn, 2005; El-Samawaty et al., 2013; Frisvad and } \\
\text { Filtenborg, 1983; Harwig et al., 1973; Larsen et al., 1998; Okeke et al., 1993; Paster } \\
\text { et al., 1995; Paterson, } 2004 \text { (IDH gene); Paterson et al., 2003; Sommer et al., 1974; } \\
\text { Steiman et al., 1989; Welke et al., } 2011\end{array}$ & \\
\hline Penicillium fellutanum & Vismer et al., 1996 & \\
\hline Penicillium funiculosum & Steiman et al., 1989; Vismer et al., 1996; Yassin et al., 2010 & \\
\hline Penicillium glabrum & Okeke et al., 1993 & \\
\hline Penicillium gladioli & Dombrinck-Kurtzman, 2007; Frisvad and Samson, 2004; Frisvad et al., 2004 & \\
\hline Penicillium glandicola & Frisvad and Filtenborg, 1989; Houbraken et al., 2016; Paterson, 2004 (IDH gene) & \\
\hline $\begin{array}{l}\text { Penicillium glandicola var. } \\
\text { glaucovenetum }\end{array}$ & Dombrinck-Kurtzman, 2007; Frisvad and Filtenborg,1989; Paterson, 2004 (IDH gene) & see $P$. concentricum \\
\hline Penicillium granulatum & Borkowska Opacka and Escoula, 1977; Frisvad et al., 1983 & see $P$. glandicola \\
\hline Penicillium griseofulvum & $\begin{array}{l}\text { Chunmei et al., 2013; Dombrinck-Kurtzman, 2007; Dombrink-Kurtzman and Blackburn, } \\
\text { 2005; Frisvad and Filtenborg, 1983, 1989; Frisvad et al., 1987; Houbraken et al., 2016; } \\
\text { Kent and Heatley, 1945; Moslem et al., 2010; Okeke et al., 1993; Oh et al., 1998; } \\
\text { Paterson, } 2004 \text { (IDH gene); Simonart and Lathouwer, 1956; Steiman et al., 1989; } \\
\text { Welke et al., } 2011\end{array}$ & \\
\hline $\begin{array}{l}\text { Penicillium griseofulvum var. } \\
\text { dipodomyicola }\end{array}$ & Frisvad and Filtenborg, 1989; Frisvad et al., 1987; Paterson, 2004 (IDH gene) & see $P$. dipodomyicola \\
\hline Penicillium hirsutum & Okeke at al., 1993; Paterson et al., 2004 & \\
\hline Penicillium italicum & Okeke et al., 1993 & \\
\hline Penicillium janczewskii & only IDH gene found, Paterson, 2004 & \\
\hline Penicillium lanosum & Kharchenko, 1970 & \\
\hline Penicillium lapidosum & Myrchink, 1967 & \\
\hline Penicillium leucopus & Anslow et al., 1943; Brian et al., 1956; Umezawa et al. 1947 & see $P$. expansum \\
\hline Penicillium lignorum & Okeke et al., 1993 & \\
\hline Penicillium maltum & Ukai et al., 1954 & see $P$. griseofulvum \\
\hline Penicillium marinum & Frisvad and Samson, 2004; Frisvad et al., 2004 & \\
\hline Penicillium melanoconidium & Luque et al., 2011 & \\
\hline Penicillium melinii & $\begin{array}{l}\text { Frisvad and Filtenborg, 1990; Karow and Forster, 1944; Okeke et al., 1993; Paterson, } \\
2004 \text { (IDH gene) }\end{array}$ & \\
\hline Penicillium miczynskii & Chunmei et al., 2013 & \\
\hline $\begin{array}{l}\text { Penicillium novae- } \\
\text { zeelandiae }\end{array}$ & Burton, 1949; Burton and Pausacker, 1947; Frisvad and Filtenborg, 1990 & \\
\hline Penicillium paneum & $\begin{array}{l}\text { Boysen et al., 1996; Dombrinck-Kurtzman, 2007; Frisvad and Samson, 2004; } \\
\text { Nielsen et al., } 2006\end{array}$ & \\
\hline Penicillium patulum & Anslow et al., 1943; Birkinshaw et al., 1943; Chain et al., 1942; Frisvad, 1981 & see $P$. griseofulvum \\
\hline Penicillium polonicum & Luque et al., 2011 & \\
\hline Penicillium psychrosexualis & Houbraken et al., 2010 & \\
\hline Penicillium puberulum & El-Samawaty et al., 2013; Moslem et al., 2011 & \\
\hline Penicillium purpurogenum & Xie et al., 2011 & \\
\hline
\end{tabular}


Table 1. Continued.

\begin{tabular}{|c|c|c|}
\hline Fungal species & References & Synonymised species \\
\hline Penicillium raistrickii & Veselá and Veselý, 1995 & \\
\hline Penicillium rivolii & Berestetskii et al., 1975 & \\
\hline Penicillium roqueforti & $\begin{array}{l}\text { Bullerman, 1978; Cakmakci et al., 2015; Chunmei et al., 2013; Erdogan et al., 2003; } \\
\text { Leistner and Pitt, 1977; Malekinejad et al., 2015; Olivigni and Steiman et al., 1989; } \\
\text { Müller and Amend, 1997; Paterson et al., 2003; Vismer et al., } 1996\end{array}$ & \\
\hline $\begin{array}{l}\text { Penicillium roqueforti } \\
\text { chemotype II }\end{array}$ & Frisvad and Filtenborg, 1983 & see $P$. paneum \\
\hline $\begin{array}{l}\text { Penicillium roqueforti var. } \\
\text { carneum }\end{array}$ & Frisvad and Filtenborg, 1989; Vismer et al., 1996 & see $P$. carneum \\
\hline Penicillium rugulosum & Leistner and Pitt, 1977; Vismer et al., 1996 & \\
\hline Penicillium samsonianum & Houbraken et al., 2016 & \\
\hline Penicillium sclerotigenum & Dombrinck-Kurtzman, 2007; Frisvad et al., 2004 & \\
\hline Penicillium selandiae & nomen nudum, in IMI Culture Collection Catalogue, 2010; Frisvad, unpublished & see $P$. antarcticum \\
\hline Penicillium simplicissimum & Okeke et al., 1993; Paterson, 2004 (IDH gene) & \\
\hline Penicillium sp. & Atkinson, 1942 & \\
\hline Penicillium spinulosum & only IDH gene, Paterson, 2004 & \\
\hline Penicillium terrestre & Atkinson et al., 1944 & \\
\hline Penicillium thomii & Borkowska Opacka and Escoula, 1977 & \\
\hline Penicillium urticae & Kent and Heatley, 1945; Yamamoto, 1954 & see $P$. griseofulvum \\
\hline Penicillium variabile & Leistner and Pitt, 1977; Steiman et al., 1989 & \\
\hline Penicillium verrucosum & Luque et al., 2011; Moslem et al., 2013; Oh et al., 1998 & \\
\hline Penicillium viridicatum & Frank, 1972 & \\
\hline Penicillium vulpinum & $\begin{array}{l}\text { Dombrinck-Kurtzman, 2007; Frisvad et al., 2004; Houbraken et al., 2016; } \\
\text { Ismaiel and Papenbrock, 2015; Ismaiel et al., } 2016\end{array}$ & \\
\hline Pestalotiopsis sp. & Okeke et al., 1993 & \\
\hline Phialophora hoffmannii & Okeke et al., 1993 & \\
\hline Pseudodiplodia sp. & Steiman et al., 1989 & \\
\hline Rhinocladiella atrovirens & Steiman et al., 1989 & \\
\hline Scopulariopsis sp. & Steiman et al., 1989 & \\
\hline Scopulariopsis flava & Okeke et al., 1993 & \\
\hline Scytalidium lignicola & Okeke et al., 1993 & \\
\hline Spicelleum roseum & Okeke et al., 1993 & \\
\hline Sporormiella minimoides & Steiman et al., 1989 & \\
\hline Sporothrix schenckii & Steiman et al., 1989 & \\
\hline Stemphylium sp. & Okeke et al., 1993 & \\
\hline Stemphylium vesicarium & Laidou et al., 2001 & \\
\hline Talaromyces purpureogenus & Ismaiel et al., 2016 & \\
\hline Talaromyces trachyspermus & Okeke et al., 1993 & \\
\hline Trametes squalens & Steiman et al., 1989 & \\
\hline Trichoderma pseudokoningii & Steiman et al., 1989 & \\
\hline Trichoderma polysporum & Steiman et al., 1989 & \\
\hline Trichophyton mentagrophytes & Steiman et al., 1989 & \\
\hline Trichophyton persicolor & Okeke et al., 1993 & \\
\hline Trichothecium roseum & Okeke et al., 1993 & \\
\hline Xylaria longiana & Edwards et al., 1999; Goss et al., 1999; Lykakis et al., 2009 & \\
\hline
\end{tabular}


and comparison to an authentic standard (Kildgaard et al., 2014). A MS/MS analysis will only yield few fragments for patulin, and thus several other verification tests have to be done to ensure that the metabolite detected is indeed patulin. In the paper by Luque et al. (2011) patulin was reported for several known producers and in addition species, such as Aspergillus flavus, Penicillium camemberti, and $P$. verrucosum. In tests of those fungi for patulin this has never been verified in those species (Frisvad et al., 2004; Varga et al., 2011b). Luque et al. (2011) used micellar capillary electrophoresis (retention time) and/or HPLCMS (retention time and MS) in addition to reporting on a PCR amplicon (496 basepairs) for the FC2/IDH gene involved in the patulin biosynthesis, and despite this, they detected patulin in species that do obviously not produce patulin. Other records of patulin producers are correct, but sometimes the fungi are just synonyms of another species. An example of this is Penicillium griseofulvum, a very efficient and consistent producer of patulin, and three of its synonyms $P$. maltum, P. patulum and $P$. urticae (Pitt, 1979) have been repeatedly reported to produce patulin (Table 1).

Given the dubious accounts of patulin production by many species, a revision of confirmed and efficient producers of patulin is given in Table 1 (species in bold). Only 29 species can be reliably said to produce patulin. Among these $P$. expansum is the most important, producing patulin in apples, pears, plums and other fruits (Dombrink-Kurtzman and McGovern, 2007; Filtenborg et al., 1996; Frisvad and Samson, 2004). Penicillium sclerotigenum, specifically associated to sweet potatoes, is also an important patulin-producing species (Yamamoto et al., 1955), as is $P$. griseofulvum that may produce patulin in wheat and malted barley (Jiménez et al., 1991; Ukai et al., 1954; Yamamoto et al., 1954). Similarly Aspergillus clavatus can produce patulin in malted barley (Lopez-Diaz and Flannigan, 1997). Penicillium dipodomyicola, another efficient patulin producer is occasionally found in foods (DombrinkKurtzman and McGovern, 2007; Frisvad and Samson, 2004). Members of Penicillium section Roquefortorum all produce patulin, except $P$. roqueforti. Since $P$. roquefort $i$ is used for blue mould cheese production, it is particularly important to know whether this fungus produces this mycotoxins. The data of Nielsen et al. (2017) show that P. roqueforti has most of the gene cluster needed for production of patulin, but some genes are missing, explaining the inability of $P$. roqueforti to produce patulin. The reports of patulin production by $P$. roqueforti (Cakmakci et al., 2015; Chunmei et al., 2013; Erdogan et al., 2003; Leistner and Pitt, 1977; Malekinejad et al., 2015; Müller and Amend, 1997; Olivigni and Bullerman, 1978; Paterson et al., 2003; Steiman et al., 1989; Vismer et al., 1996) appear to be caused by misidentifications, because the closely related species $P$. carneum and $P$. paneum both produce patulin (Boysen et al., 1996). Paecilomyces fulvus (formerly Byssochlamyes fulva),
Paecilomyces niveus (formerly Byssochlamys nivea) and Paecilomyces saturatus have all been reported to produce patulin. There has been some doubt whether Pae. fulvus can produce patulin (reported by Escoula, 1974; Paterson, 2004 and Sant'Ana et al., 2010, but rejected by Puel et al., 2007), but these species all have heat resistant ascospores (Samson et al., 2009), and thus may survive in pasteurised fruit juices and produce patulin (Rice et al., 1977; Sant'Ana et al., 2010). Paecilomyces niveus and Penicillium paneum can grow in substrates with a high concentration of acetic acid and thus can also be found in silage, and may produce patulin there (Gallo et al., 2015; O’Brien et al., 2006; Scurti et al., 1973). P. antarcticum is a marine-derived Penicillium species and may produce patulin on seaweed or even in shellfish (Geiger et al., 2013; Vansteelandt et al., 2012). Penicillium marinum is also marine-derived and may produce patulin in the same seaborne organisms (Frisvad and Samson, 2004).

The remaining species producing patulin are of less consequence for mycotoxin production in foods. Penicillium gladioli may potentially produce patulin in gladiolus bulbs, and Penicillium glandicola can potentially produce patulin on acorns, but flower bulbs and acorns are not used for food or feed. Penicillium compactum, Penicillium novaezeelandiae and Penicillium samsonianum are soil or grass-borne fungi (Houbraken et al., 2016) and Aspergillus longivesica, Aspergillus giganteus, Penicillium clavigerum, Penicillium concentricum, Penicillium coprobium, Penicillium formosanum, and P. vulpinum are all dung fungi and of no consequence for food safety (Frisvad and Samson, 2004).

For all of the species listed above, patulin has been detected in a large number of isolates of the producing species, for example patulin was detected in 83 out of 85 isolates of $P$. expansum by Andersen et al. (2004), and produced by $350 / 357$ isolates out of $P$. expansum, by 40 out of 40 isolates in P. griseofulvum, by 13/13 isolates in P. coprobium, by $14 / 14$ isolates in $P$. glandicola, by $14 / 15$ strains of $P$. concentricum ( $=P$. glandicola var. glaucovenetum), by 10/12 isolates of $P$. carneum ( $=P$. roqueforti var. carneum), by $4 / 4$ isolates of $P$. dipodomyicola $(=P$. griseofulvum var. dipodomyicola) and by 6/6 isolates of $P$. vulpinum (Frisvad and Filtenborg, 1989), showing a high consistency in patulin production by these species.

\section{Penicillic acid and producing organisms}

Penicillic acid is the main product of the biosynthetic pathway that starts with orsellinic acid and has penicillic acid as end product (Axberg and Gatenbeck, 1975a,b; Eldridge et al., 1977). However there are other members of the penicillic acid pathway, including 5,6-dihydropenicillic acid, 5,6-dihydro-6-hydroxypenicillic acid, 6-methoxy5,6-dihydropenicillic acid, coculnol, and (4R,5R)-4,5- 
dihydroxy-3-methoxy-5-methylcyclohex-2-en-1-one (He et al., 2004; Kimura et al., 1996; Nonaka et al., 2015; Obana et al., 1995a,b; Phainuphong et al., 2017; Qi et al., 2015; Raphael, 1947a,b; Shiono et al., 2005).

Penicillic acid has been reported in 101 species, varieties and chemotypes of fungi (Table 2), of which 48 are regarded as well documented. Some of the data may be incorrect connections between fungal species and penicillic acid because of carry over in the chromatographic system, or contamination by penicillic acid producing species. In the paper by Gutarowska et al. (2010), Aspergillus niger and Aspergillus flavus are reported to produce penicillic acid, and this has never been reported from these Aspergilli in any other papers. Again the isolates have not been accessioned in any fungal collection, but furthermore, the concomitant detection of penicillic acid and viridicatin indicates that the cultures of $A$. flavus and $A$. niger were contaminated with Penicillium cyclopium, which is a known producer of these two secondary metabolites. In the control sample on malt extract agar (MEA) with no fungi inoculated, Gutarowska et al. (2010) found kojic acid, indicating that a kojic acid producer had been growing in the barley malt before it was made into malt extract.

Producers of penicillic acid are especially common in Penicillium section Viridicata and in Aspergillus section Circumdati (Frisvad and Samson, 2000; Frisvad et al., 2004a; Visagie et al., 2014a). One can therefore expect a mycotoxin cocktail in mouldy cereals consisting of citrinin, ochratoxin A, penicillic acid, verrucosidin, nephrotoxic glycopeptides, xanthomegnin, viomellein, vioxanthin, moniliformin, and penitrem A when associated storage fungal species, such as $P$. verrucosum, $P$. aurantiogriseum, P. polonicum, P. viridicatum, P. cyclopium and Penicillium freii have grown on those cereals in a worst case scenario (Frisvad and Samson, 2004; Frisvad et al., 2004; HallasMøller et al., 2016; Lund and Frisvad, 1994). Most species in Aspergillus section Circumdati, such as Aspergillus westerdijkiae, Aspergillus steynii and Aspergillus ochraceus also produce one or more of the mycotoxins ochratoxin A, penicillic acid, xanthomegnin, viomellein and vioxanthin (Visagie et al., 2014a). Penicillic acid has been found in many sections of Penicillium, including Brevicompacta, Canescentia, Chrysogena, Exilicaulis, Fasciculata, LanataDivaricata, Ramosa, Roquefortorum and Turbatum, so this is found in many phylogenetic groups of Penicillium. Penicillic acid has only been found in one section of Aspergillus: Circumdati.

Other species listed in Table 2 producing penicillic acid include soil borne species, such as Penicillium baarnense, Penicillium egyptiacum, and Penicillium jamesonlandense, grass-associated fungi, such as Penicillium brasilianum and dung fungi, such as Penicillium bovifimosum also produce penicillic acid, but such fungi will probably not grow in foods or feeds, and are less relevant for food safety.

Among the common species producing penicillic acid, there is a high consistency in producing this mycotoxin. In P. aurantiogriseum, more than 278 isolates out of 385 examined produced penicillic acid, and it was produced by $17 / 17$ isolates of $P$. melanoconidium, by $35 / 53$ isolates of Penicillium neoechinulatum, by 234/276 isolates of $P$. polonicum, and by $324 / 350$ isolates of $P$. viridicatum (Frisvad and Filtenborg, 1989).

Terrestric acid, often co-occurring with penicillic acid, is produced by cereal borne fungi such as $P$. aurantiogriseum, $P$. tricolor and $P$. hordei, by onion and bulb associated fungi, such as $P$. radicicola, $P$. tulipae, and $P$. venetum in addition to being produced by the apple, cheese and nut associated $P$. crustosum and the rice associated fungus $M$. grisea (Frisvad and Samson, 2004; Yu et al., 2010) (Table 3). This toxin may thus co-occur in cereals with penicillic acid, moniliformin, ochratoxin A, verrucosidins, and xanthomegnins (Frisvad and Samson, 2004).

\section{Moniliformin and producing microorganisms}

Moniliformin is a mycotoxin that was first reported from Fusarium moniliforme (Cole et al., 1973), but has since been reported to be produced by many species in that genus (Table 4). It is biosynthesised from two acetyl units (Franck and Breipohl, 1984; Gathercole et al., 1986). Most of the producers of moniliformin have been confirmed by data from later papers (Table 4), and rejected producers mostly are only synonyms of names later accepted. Most of these 40 species reported to produce moniliformin do indeed produce it, except for 6 species, where Schütt et al. (1998) could not confirm production by these species. It should be noted that moniliformin production is difficult to verify because of the low molecular weight and simple MS fragmentation pattern, so often TLC and the characteristic UV spectrum has been used to confirm identity. In the database on natural products called AntiBase, among more than 40,000 compounds, only one has a formula of $\mathrm{C}_{4} \mathrm{H}_{2} \mathrm{O}_{3}$, so simple HR-MS data are also confirmative of production. In addition to its production by Fusarium species, Penicillium melanoconidium has been reported to produce moniliformin (Hallas-Møller et al., 2016). A large number of these species are cereal-borne, including P. melanoconidium which has, however, only been found on stored cereals. However, other species of Fusarium are pathogens on potatoes, tomatoes, onions, etc. (Lesley and Summerell, 2016), and thus moniliformin can occur in many cereals, fruits and vegetables. Furthermore, moniliformin is produced by isolates of Fusarium fusaroides from millet, sorghum, dried fish and peanuts (Rabie et al., 1978). In addition Fusarium species produce several other mycotoxins concomitantly, such as trichothecenes, zearalenone, 
Table 2. Filamentous fungi claimed as producers of penicillic acid. ${ }^{1}$

\begin{tabular}{|c|c|c|}
\hline Fungal species & References & Synonymised species \\
\hline Aspergillus affinis & Visagie et al., 2014a & \\
\hline Aspergillus auricomus & Ciegler 1972; Frisvad et al., 2004a; Visagie et al., 2014a & \\
\hline Aspergillus bridgeri & Frisvad et al., 2004a; Kumar et al., 2011; Visagie et al., 2014a & \\
\hline Aspergillus cervinus & He et al., 2004 & \\
\hline Aspergillus cretensis & Frisvad et al., 2004a; Visagie et al., 2014a & \\
\hline Aspergillus elegans & Obana et al., 1995b & \\
\hline Aspergillus flavus & Gutarowska et al., 2010 & \\
\hline Aspergillus flocculosus & Frisvad et al., 2004a; Montenegro et al., 2012; Visagie et al., 2014a & \\
\hline Aspergillus fumigatus & Şenyuva et al., 2008 & \\
\hline Aspergillus insulicola & Frisvad et al., 2004a; Visagie et al., 2014a & \\
\hline Aspergillus melleus & $\begin{array}{l}\text { Ciegler, 1972; Frisvad et al., 2004a; Gill-Carey 1949; Obana et al., 1995b; } \\
\text { Visagie et al., 2014a }\end{array}$ & \\
\hline Aspergillus muricatus & Frisvad and Samson, 2000; Frisvad et al., 2004a; Visagie et al., 2014a & \\
\hline Aspergillus neobridgeri & Frisvad et al., 2004a; Visagie et al., 2014a & \\
\hline Aspergillus nidulans & Abu-Seidah, 2003 & \\
\hline Aspergillus niger & Gutarowska et al., 2010 & \\
\hline Aspergillus occultus & Visagie et al., 2014a & \\
\hline $\begin{array}{l}\text { Aspergillus } \\
\text { ochraceopetaliformis }\end{array}$ & Visagie et al., 2014a & \\
\hline Aspergillus ochraceus & $\begin{array}{l}\text { Ciegler, 1972; El-Shanawany et al., 2005; Frisvad et al., 2004a; Garza et al., 1993; } \\
\text { Karow et al., 1944; Northolt et al., 1979; Obana et al., 1995b; Visagie et al., 2014a }\end{array}$ & \\
\hline Aspergillus ostianus & $\begin{array}{l}\text { Ciegler, 1972; Frisvad et al., 2004a; Namikoshi et al., 2003; Obana et al., 1995b; } \\
\text { Visagie et al., 2014a }\end{array}$ & \\
\hline Aspergillus pallidofulvus & Visagie et al., 2014a & \\
\hline Aspergillus persii & Frisvad et al. 2004a; Visagie et al., 2014a & \\
\hline Aspergillus petrakii & Frisvad et al., 2004a & see A. ochraceus \\
\hline Aspergillus pseudoelegans & Frisvad et al., 2004a & \\
\hline Aspergillus pulvericola & Visagie et al., 2014a & \\
\hline Aspergillus quercinus & Gill-Carey, 1949 & \\
\hline Aspergillus salwaensis & Visagie et al., 2014a & \\
\hline $\begin{array}{l}\text { Aspergillus } \\
\text { roseoglobulosus }\end{array}$ & Frisvad et al., 2004a; Visagie et al., 2014a & \\
\hline Aspergillus sclerotiorum & $\begin{array}{l}\text { Ciegler, 1972; Frisvad et al., 2004a; Kang and Kim, 2004; Kang et al., 2007; } \\
\text { Obana et al., 1995b; Visagie et al., 2014a; Zheng et al., } 2010\end{array}$ & \\
\hline Aspergillus sp. & Li et al., 2010 & \\
\hline Aspergillus subramanianii & Visagie et al., 2014a & \\
\hline Aspergillus sulphureus & Ciegler, 1972; Frisvad et al., 2004a; Gill-Carey, 1949 & \\
\hline Aspergillus violaceus & Abu-Seidah, 2003 & \\
\hline Aspergillus wentii & He et al., 2004 & \\
\hline Aspergillus westerdijkiae & Frisvad et al., 2004a; Visagie et al., 2014a & \\
\hline Aspergillus westlandensis & Visagie et al., 2014a & \\
\hline Eupenicillium bovifimosum & Tuthill and Frisvad, 2002 & see $P$. bovifimosum \\
\hline Exophiala sp. & Zhang et al., 2008 & \\
\hline Malbranchea aurantiaca & Martínez-Luis et al., 2005 & \\
\hline Paecilomyces ehrlichii & Gorbach and Friederick, 1949 & \\
\hline Penicillium atramentosum & Bridge et al., 1989 & \\
\hline Penicillium aurantiogriseum & $\begin{array}{l}\text { Bridge et al. 1989; Bokhari and Flannigan, 1996; El-Banna et al., 1987; Frisvad and } \\
\text { Filtenborg 1983; Frisvad et al., 2004b; Garza et al., 1993; Khaddor et al., 2007; } \\
\text { Lund and Frisvad 1994; Mills et al., 1995a,b; Oh et al., } 1998\end{array}$ & \\
\hline $\begin{array}{l}\text { Penicillium aurantiogriseum } \\
\text { var. polonicum }\end{array}$ & Frisvad and Filtenborg, 1989 & see $P$. polonicum \\
\hline $\begin{array}{l}\text { Penicillium aurantiogriseum } \\
\text { var. neoechinulatum }\end{array}$ & Frisvad et al., 1987 & see $P$. neoechinulatum \\
\hline
\end{tabular}


Table 2. Continued.

\begin{tabular}{|c|c|c|}
\hline Fungal species & References & Synonymised species \\
\hline $\begin{array}{l}\text { Penicillium aurantiogriseum } \\
\text { var. melanoconidium }\end{array}$ & Frisvad and Filtenborg, 1989 & see $P$. melanoconidium \\
\hline Penicillium aurantiovirens & Lund and Frisvad, 1994; Wirth and Klosek, 1972 & $\begin{array}{l}\text { presently regarded as a } \\
\text { synonym of } P \text {. cyclopium }\end{array}$ \\
\hline Penicillium baarnense & Burton, 1949; Mosbach, 1960 & \\
\hline Penicillium bovifimosum & Tuthill and Frisvad, 2002; Visagie et al., 2014b & \\
\hline Penicillium brasilianum & Frisvad, 1989; Frisvad and Filtenborg, 1990 & \\
\hline & Schurman et al., 2010 & \\
\hline Penicillium brevicompactum & Paterson et al., 1987 & \\
\hline Penicillium canescens & Keromnes and Thouvenot, 1985; Kharchenko, 1970 & \\
\hline Penicillium carneum & Boysen et al., 1996; Frisvad et al., 2004 & \\
\hline Penicillium castellae & Quintanilla, 1982 & see $P$. raistrickii \\
\hline Penicillium chrysogenum & Jiménez et al., 1991; Leistner and Pitt, 1977; Oyero and Oyefulo, 2009 & \\
\hline Penicillium citrinum & Delgado et al., 2011; El-Samawaty et al., 2013 & \\
\hline Penicillium claviforme & Ueno, 1994 & \\
\hline Penicillium commune & Ciegler et al., 1972; Mintzlaff et al., 1972 & \\
\hline Penicillium cordubense & Skóra et al., 2017 & see P. polonicum \\
\hline Penicillium cremeogriseum & Frisvad and Filtenborg, 1990 & \\
\hline Penicillium cyclopium & $\begin{array}{l}\text { Bentley and Keil, 1962; Birkinshaw et al., 1936; Ciegler et al., 1972; Frisvad and } \\
\text { Samson, 2004; Jiménez et al., 1991; Keromnes and Thouvenot, 1985; Lei et al., 2010; } \\
\text { Lindenfelser and Ciegler, 1977; Lund and Frisvad, 1994; Mintzlaff et al., 1972; } \\
\text { Northolt et al., } 1979\end{array}$ & \\
\hline Penicillium expansum & Ciegler et al., 1972; Mintzlaff et al., 1972; Patterson and Damoglou, 1985 & \\
\hline Penicillium fennelliae & Van Eijk, 1969 & \\
\hline Penicillium freii & Frisvad et al., 2004; Lund and Frisvad, 1994 & \\
\hline Penicillium frequentans & Yamaji et al., 2005 & \\
\hline Penicillium funiculosum & Nasser, 2008 & \\
\hline Penicillium granulatum & Bridge et al., 1989 & \\
\hline Penicillium griseofulvum & Moslem et al., 2010; Reio, 1958 & \\
\hline Penicillium griseum & Gorbach and Friederick, 1949 & \\
\hline Penicillium hirsutum & Bridge et al., 1989; Ezzat et al., 2007 & \\
\hline $\begin{array}{l}\text { Penicillium hirsutum var. } \\
\text { albocoremium }\end{array}$ & Frisvad and Filtenborg, 1989 & \\
\hline Penicillium islandicum & Nasser, 2008 & \\
\hline $\begin{array}{l}\text { Penicillium } \\
\text { jamesonlandense }\end{array}$ & Frisvad et al., 2006 & \\
\hline Penicillium janczewskii & Frisvad and Filtenborg, 1990 & \\
\hline Penicillium janthinellum & Ciegler et al., 1972; Mintzlaff et al., 1972 & \\
\hline Penicillium lilacinum & Kharchenko, 1970 & \\
\hline Penicillium lividum & Gorbach and Friederick, 1949 & \\
\hline Penicillium madriti & Birkinshaw and Gowlland, 1962 & also named $P$. matriti \\
\hline Penicillium martensii & $\begin{array}{l}\text { Kurtzman and Ciegler, 1970; Lillehoj et al., 1972; Mintzlaff et al., 1972; } \\
\text { Northolt et al., 1979; Wirth et al., } 1956\end{array}$ & \\
\hline Penicillium megasporum & $\begin{array}{l}\text { Nozawa et al., 1989; not a Penicilium (Frisvad and Filtenborg, 1990; } \\
\text { Visagie et al., 2014b) }\end{array}$ & \\
\hline $\begin{array}{l}\text { Penicillium } \\
\text { melanoconidium }\end{array}$ & Lund and Frisvad 1994; Frisvad and Samson, 2004 & \\
\hline Penicillium neoechinulatum & Lund and Frisvad 1994; Frisvad and Samson, 2004 & \\
\hline Penicillium ochraceum & Tsunoda et al., 1978 & see $P$. viridicatum \\
\hline Penicillium olivinoviride & Kobayashi et al., 1971 & see $P$. viridicatum \\
\hline Penicillium oxalicum & Oh et al., 1998 & \\
\hline
\end{tabular}


Table 2. Continued.

\begin{tabular}{|c|c|c|}
\hline Fungal species & References & Synonymised species \\
\hline Penicillium palitans & Ciegler and Kurtzman, 1970 & \\
\hline Penicillium paraherquei & Leistner and Eckardt, 1979 & \\
\hline Penicillium piscarium & Leistner and Pitt, 1977 & \\
\hline Penicillium polonicum & Frisvad and Samson, 2004; Lund and Frisvad, 1994; Skóra et al., 2017 & \\
\hline Penicillium puberulum & Alsberg and Black 1913; El-Samawaty et al., 2013; Moslem et al., 2011 & see $P$. cyclopium \\
\hline Penicillium pulvillorum & Frisvad and Filtenborg, 1990 & \\
\hline Penicillium radicicola & Frisvad and Samson, 2004; Overy and Frisvad, 2003, 2005 & \\
\hline Penicillium raistrickii & Bridge et al., 1989; Frisvad, 1988; Frisvad and Filtenborg, 1990 & \\
\hline Penicillium rolfsii & Frisvad, 1989 & \\
\hline Penicillium roqueforti & $\begin{array}{l}\text { Bridge et al., 1989; Cakmakci et al., 2012, 2015; Erdogan et al., 2003; Moubasher et al., } \\
\text { 1978; Malekinejad et al., 2015; Mioso et al., 2015; Müller and Amend, 1997; } \\
\text { Olivigni and Bullerman, } 1978\end{array}$ & \\
\hline Penicillium simplicissimum & $\begin{array}{l}\text { Betina et al., 1969; Ciegler et al., 1972; El-Banna et al., 1987; Mintzlaff et al., 1972; } \\
\text { Takahashi et al., } 2008\end{array}$ & \\
\hline Penicillium solitum & Bridge et al., 1989 & \\
\hline Penicillium sp. & Komagata et al., 1996; Tachibana et al., 2008 & \\
\hline Penicillium stoloniferum & $\begin{array}{l}\text { Alsberg and Black, 1913; Clutterbuck et al., } 1932 \\
\text { Ciegler et al., 1972; Lindenfelser and Ciegler, } 1977\end{array}$ & \\
\hline Penicillium suavolens & Karow et al., 1944 & see $P$. carneum \\
\hline Penicillium subrubescens & Mansouri et al., 2013 & \\
\hline Penicillium thomi/P. thomii & Karow et al. 1944; Casquete et al., 2017 & \\
\hline Penicillium tulipae & Frisvad and Samson, 2004; Overy and Frisvad, 2003; Overy et al., 2005; & \\
\hline $\begin{array}{l}\text { Penicillium } \\
\text { vanderhammenii }\end{array}$ & Houbraken et al., 2011 & \\
\hline Penicillium verrucosum & Gedek et al., 1981; Moslem, 2013; Oh et al., 1998 & \\
\hline Penicillium viridicatum & $\begin{array}{l}\text { Bresler et al., 1995; Ciegler et al., 1972, 1973; Frisvad and Samson, 2004; } \\
\text { Jiménez et al., 1991; Lund and Frisvad, 1994; Mintzlaff et al., 1972; Northolt et al., 1979; } \\
\text { Oh et al., } 1998\end{array}$ & \\
\hline Trichoderma spp. $^{2}$ & Lebed et al., 1978 & \\
\hline
\end{tabular}

enniatins and several other mycotoxins or emerging mycotoxins (Brase et al., 2009; Gruber-Dorninger et al., 2017; Neme and Mohammed, 2017). Since moniliformin is produced by so many species one can maybe expect that apart from its mammal and plant toxicity, it could have antibiotic or quorum sensing inhibition abililites.

\section{Conclusions}

The small acidic lactone mycotoxins, such as patulin, penicillic acid and moniliformin can occur in many foods and feeds, and are toxic by themselves, but often there may be a potential synergistic or additive effect with other co-occurring mycotoxins. Based on the species producing patulin, fruit products are most prone to contamination with this mycotoxin. Penicillic acid is more common on stored cereals, as the best producers are mostly cereal-borne.
Moniliformin is produced by a large number of Fusarium species, and many of those are common on cereals, but also on fruits and vegetables. Among a large number of species reported to produce patulin and penicillic acid, only 29 and 48 species, respectively, have been reliably reported to produce them. The species producing them are mostly belonging to Penicillum and Aspergillus. Moniliformin is produced by 34 Fusarium species and by one species of Penicillium. The revised lists of producers of these mycotoxins will aid in preventive mycotoxin work, but also help in de-selecting known producers of these antibiotic toxins, when screening for new antibiotics. 
Table 3. Filamentous fungi reported as producers of terrestric acid. ${ }^{1}$

\begin{tabular}{|c|c|c|}
\hline Fungal species & References & Synonymised species \\
\hline Magnaporthe oryzae & Couch and Kohn, 2002 (taxonomy); Yu et al., 2010 & \\
\hline Pyricularia oryzae & Yu et al., 2010 & see $M$. oryzae \\
\hline Penicillium aurantiogriseum & Frisvad and Samson, 2004; Lund and Frisvad, 1994 & \\
\hline $\begin{array}{l}\text { Penicillium aurantiogriseum } \\
\text { var. aurantiogriseum }\end{array}$ & Frisvad and Filtenborg, 1989 & see $P$. aurantiogriseum \\
\hline Penicillium crustosum & Frisvad and Filtenborg, 1989; Frisvad and Samson, 2004; Sonjak et al., 2005 & \\
\hline Penicillium griseoroseum & Da Silva et al., 2013 & \\
\hline Penicillium hirsutum & Frisvad and Samson, 2004; Overy and Frisvad, 2003; Overy et al., 2005 & \\
\hline $\begin{array}{l}\text { Penicillium hirsutum var. } \\
\text { albocoremium }\end{array}$ & Frisvad and Filtenborg, 1989 & \\
\hline $\begin{array}{l}\text { Penicillium hirsutum var. } \\
\text { hirsutum }\end{array}$ & Frisvad and Filtenborg, 1989 & see $P$. hirsutum \\
\hline $\begin{array}{l}\text { Penicillium hirsutum var. } \\
\text { hordei }\end{array}$ & Frisvad and Filtenborg, 1989 & see $P$. hordei \\
\hline $\begin{array}{l}\text { Penicillium hirsutum var. } \\
\text { venetum }\end{array}$ & Frisvad and Filtenborg, 1989 & see $P$. venetum \\
\hline Penicillium hordei & Frisvad and Samson, 2004; Overy et al., 2005 & \\
\hline Penicillium terrestre & Birkinshaw and Samant, 1960 & see $P$. crustosum \\
\hline Penicillium tricolor & Frisvad and Samson, 2004; Frisvad et al., 1994 & \\
\hline Penicillium radicicola & Overy and Frisvad, 2003; Overy et al., 2005 & \\
\hline Penicillium tulipae & Overy and Frisvad, 2003; Overy et al., 2005 & \\
\hline Penicillium venetum & Frisvad and Samson, 2004; Overy and Frisvad, 2003; Overy et al., 2005 & \\
\hline Penicillium viridicatum & Birkinshaw and Samant, 1960 & \\
\hline
\end{tabular}

\section{Acknowledgements}

This work was supported by The Novo Nordic Foundation (NNF13OC0005201) and the Danish National Research Foundation (DNRF137) for the Center for Microbial Secondary Metabolites, and by an Agilent Thought Leader Award (\#2871).

\section{References}

Abbas, H.K., Boyette, C.D. and Hoagland, R.E., 1995. Phytotoxicity of Fusarium, other fungal isolates, and of the phytotoxins fumonisin, fusaric acid, and moniliformin to jimsonweed. Phytoprotection 76: $17-25$.

Abu-Seidah, A.A., 2003. Secondary metabolites as co-markers in the taxonomy of aspergilli. Acta Microbiologica Polonica 52: 15-23.

Alsberg, C.I. and Black, O.F., 1913. Contribution to the study of maize deterioration; biochemical and toxicological investigations of Penicillium puberulum and Penicillium stoloniferum. USDA Bureau Plant Industry Bulletin 270: 7-48.
Andersen, B., Smedsgaard, J. and Frisvad, J.C., 2004. Penicillium expansum: consistent production of patulin, chaetoglobosins, and other secondary metabolites in culture and their natural occurrence in fruit products. Journal of Agricultural and Food Chemistry 52: 2421-2428.

Anslow, W.K., Raistrick, H. and Smith, G., 1943. Antifungal substances from molds; patulin (anhydro-3-hydroxymethylene-tetrahydro1:4-pyrone-2-carboxylic acid), a metabolic product of Penicillium patulum Bainier and Penicillium expansum (Link) Thom. Journal of the Indian Chemical Society 62: 236-238.

Aoki, T., O’Donnell, K. and Geiser, D.M., 2014. Systematics of key phytopathogenic Fusarium species: current status and future challenges. Journal of General Microbiology 80: 189-201.

Appell, M., Dombrinnk-Kurtzman, M.A. and Kendra, D.F., 2009. Comparative study of patulin, ascladiol, and neopatulin by density function theory. Journal of Molecular Structure: THEOCHEM 894: 23-31.

Atkinson, N., 1942. Antibacterial substances produced by moulds. I. Penicidin, a product of the growth of a Penicillium. Australian Journal of Experimental Biology and Medical Science 20: 287. 
Table 4. Filamentous fungi reported as producers of moniliformin. ${ }^{1}$

\begin{tabular}{|c|c|}
\hline Fungal species & References \\
\hline Fusarium acuminatum & Bosch and Mirocha, 1992; Hussein et al., 1991; Logrieco et al., 1992; Rabie et al., 1982; Schütt et al., 1998 \\
\hline Fusarium acutatum & Schütt et al., 1998 \\
\hline Fusarium anthophilum & Marasas et al., 1986; Schütt et al., 1998 \\
\hline Fusarium arthrosporioides & Schütt et al., 1998 \\
\hline Fusarium avenaceum & Bosch and Mirocha, 1992; Rabie et al., 1982; Schütt et al., 1998 \\
\hline Fusarium begoniae & Fotso et al., 2002; Schütt et al., 1998 \\
\hline Fusarium beomiforme & Marasas et al., 1991; Schütt et al., 1998 \\
\hline Fusarium bulbicola & Schütt et al., 1998 \\
\hline Fusarium chlamydosporum & Schütt et al., 1998 \\
\hline Fusarium concentricum & Schütt et al., 1998 \\
\hline Fusarium concolor ${ }^{2}$ & Rabie et al., 1982 \\
\hline Fusarium culmorum ${ }^{2}$ & Scott et al., 1987 \\
\hline Fusarium denticulatum & Fotso et al., 2002; Schütt et al., 1998 \\
\hline Fusarium denticulatum & Schütt et al., 1998 \\
\hline Fusarium dlamini & Schütt et al., 1998 \\
\hline 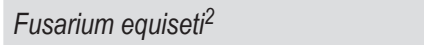 & Bosch and Mirocha, 1992; Hussein et al., 1991; Rabie et al., 1982 \\
\hline Fusarium fujikuroi (Bakane strains) & Marasas et al., 1986, 1991; Schütt et al., 1998 \\
\hline Fusarium fusaroides & Rabie et al., 1978, 1982 \\
\hline Fusarium lactis & Fotso et al., 2002; Schütt et al., 1998 \\
\hline${\text { (Fusarium moniliforme })^{2}}^{2}$ & $\begin{array}{l}\text { Cole et al., 1973; Burmeister et al., 1979; Hussein et al., 1991; Marasas et al., 1986; Rabie et al., 1982; Tseng, } \\
1993\end{array}$ \\
\hline $\begin{array}{l}\text { Fusarium moniliforme var. } \\
\text { subglutinans (Fusarium sacchari } \\
\text { var. subglutinans) }{ }^{2}=\text { Fusarium } \\
\text { subglutinans (see this) }\end{array}$ & $\begin{array}{l}\text { Bosch and Mirocha, 1992; Bosch et al., 1992; Hussein et al., 1991; Kriek et al., 1977; Lew et al., 1996; } \\
\text { Logrieco et al., 1993; Marasas et al., 1986; Rabie et al., } 1982\end{array}$ \\
\hline Fusarium napiforme & Marasas et al., 1991; Schütt et al., 1998 \\
\hline Fusarium nisikadoi & Fotso et al., 2002; Schütt et al., 1998 \\
\hline Fusarium nygamai & Marasas et al., 1988; 1991; Schütt et al., 1998 \\
\hline Fusarium oxysporum & Abbas et al., 1995; Hussein et al., 1991; Rabie et al., 1982; Schütt et al., 1998 \\
\hline Fusarium phyllophilum & Fotso et al., 2002; Schütt et al., 1998 \\
\hline Fusarium proliferatum & $\begin{array}{l}\text { Logrieco and Bottalico, 1988; Logrieco et al., 1995; Marasas et al., 1986; Miller et al., 1995; Scarpino et al., } \\
\text { 2015; Schütt et al., } 1998\end{array}$ \\
\hline Fusarium pseudoanthophilum & Schütt et al., 1998 \\
\hline Fusarium pseudocircinatum & Fotso et al., 2002; Schütt et al., 1998 \\
\hline Fusarium pseudonygamai & Fotso et al., 2002; Schütt et al., 1998 \\
\hline Fusarium ramigenum & Fotso et al., 2002; Schütt et al., 1998 \\
\hline Fusarium redolens & Schütt et al., 1998 \\
\hline Fusarium sacchari & Schütt et al., 1998 \\
\hline Fusarium semitectum & Rabie et al., 1982; \\
\hline Fusarium sporotrichioides ${ }^{2}$ & Scott et al.; 1987 \\
\hline Fusarium subglutinans & $\begin{array}{l}\text { Bosch and Mirocha, 1992; Bosch et al., 1992; Hussein et al., 1991; Kriek et al., 1977; Marasas et al., 1986; } \\
\text { Lew et al., 1996; Logrieco et al., 1993; Rabie et al., 1982; Schütt et al., } 1998\end{array}$ \\
\hline Fusarium temperatum & Scauflaire et al., 2011; Sewram et al., 1999 \\
\hline Fusarium thapsinum & Schütt et al., 1998 \\
\hline Fusarium tricinctum & Schütt et al., 1998 \\
\hline Penicillium melanoconidium & Hallas-Møller et al., 2016 \\
\hline
\end{tabular}


Atkinson, N., Sheppard, R.A.W., Stanley, N.F. and Rainsford, K.M., 1944. Antibacterial substances produced by moulds. 7. The activity of a further group of Australian strains of Penicillium and Aspergillus. Australian Journal of Experimental Biology and Medical Science 22: 227-230.

Axberg, K. and Gatenbeck, S., 1975a. Intermediates in the penicillic acid biosynthesis in Penicillium cyclopium. Acta Chemica Scandinavica B29: 749-751.

Axberg, K. and Gatenbeck, S., 1975b. The enzymatic formation of penicillic acid. FEBS Letters 54: 18-20.

Bacon, C.W., Hinton, D.M. and Motchell, T.R., 2017. Is quorum signalling by mycotoxins a new risk-mitigating strategy for bacterial control of Fusarium verticillioides and other endophytic fungal species? Journal of Agricultural and Food Chemistry 65: 7071-7080.

Ballester, A.R., Marcet-Houben, M., Levin, E., Sela, N., Selma-Lazaro, C., Carmona, L., Wisniewski, M., Droby, S., Gonzales-Candelas, L. and Galbadon, T., 2015. Genome, transcriptome, and functional analyses of Penicillium expansum provide new insights into secondary metabolism and pathogenicity. Molecular Plant-Microbe Interactions Journal 28: 232-248.

Banani, H., Marcet-Houben, M., Ballester, A.-R., Abbruscato, P., González-Candelas, L., Gabaldón, T. and Spadero, D., 2016. Genome sequencing and secondary metabolism of the postharvest pathogen Penicillium griseofulvum. BMC Genomics 17: 19.

Barad, S., Espeso, E.A., Sherman, A. and Prusky, D., 2016a. Ammonia activates $\mathrm{pac} C$ and patulin accumulation in an acidic environment during apple colonization by Penicillium expansum. Molecular Plant Pathology 17: 727-740.

Barad, S., Horowitz, S.B., Kobiler, I., Sherman, A. and Prusky, D., 2014. Accumulation of the mycotoxin patulin in presence of gluconic acid contributes to pathogenicity of Penicillium expansum. Molecular Plant-Microbe Interactions Journal 27: 66-77.

Barad, S., Horowitz, S.B., Moskovitch, O., Lichter A., Sherman, A. and Prusky, D., 2012. A Penicillium expansum glucose oxidaseencoding gene, GOX2, is essenatial for gluconic acid production and acidification during colonization of deciduous fruit. Molecular Plant-Microbe Interactions Journal 25: 779-788.

Barad, S., Sela, N., Kumar, D., Kumar-Dubey, A., Glam-Matana, N., Sherman, A. and Prusky, D., 2016c. Fungal and host transcriptome analysis of pH-regulated genes during colonization of apple fruits by Penicillium expansum. BMC Genomics 17: 330.

Barad, S., Sionov, E. and Prusky, D., 2016b. Role of patulin in postharvest diseases. Fungal Biology Reviews 30: 24-32.

Barta, J. and Mecir, R., 1948. Antibacterial activity of Penicillium divergens Bainier. Experientia 4: 277-278.

Bemi, E., 2004. Patulin: properties, occurrence in food and regulation. A review. Industria Conserve 79: 425-440.

Bennett, M., Gill, G.B., Pattenden, G. and Shuker, A.J., 1990. A total synthesis of neopatulin. Synlett 1990: 455-456.

Bennett, M., Gill, G.B., Pattenden, G., Shuker, A.J. and Stapleton, A., 1991. Ylidenebutenolide mycotoxins - concise synthesis of patulin and neopatulin from carbohydrate precursors. Journal of the Chemical Society, Perkin Transactions 1: 929-937.

Bentley, R. and Keil, J.G., 1962. Tetronic acid biosynthesis in molds. II. Formation of penicillic acid in Penicillium cyclopium. Journal of Biological Chemistry 237: 867-873.
Berestetskii, O.A., Patyka, V.F. and Kalmykova, N.A. 1975. Isolation and identification of a phytotoxic substance from Penicillium rivolii strain 1066. Microbiologichny Zhurnal (Kiev) 37: 11-14.

Berestetskii, O.A., Nadkernichnyi, S.P. and Patyka, V.F., 1974. Formation of patulin from Penicillium cyaneofulvum. Khimiya Prirodnykh Soedinenii 1974: 420-421. (Chemical Abstracts 13062r, 1975).

Beretta, B., Gaiaschi, A., Galli, C.L. and Restani, P., 2000. Patulin in apple-based foods: occurrence and safety evaluation. Food Additives and Contaminants 17: 399-406.

Bergel, F., Morrison, A.L., Klein, R., Moss, A.R., Rinderknecht, H. and Ward, J.L., 1943. An antibiotic substance from Aspergillus clavatus and Penicillium claviforme and its probable identity with patulin. Nature 152: 750.

Bergel, F., Morrison, A.L., Moss, A.R. and Rinderknecht, H., 1944. An antibiotic substance from Aspergillus clavatus. Journal of the Chemical Society: 415-421.

Bernhoft, A., Keblys, M., Morison, E., Larsen, H.J.S. and Flaoyen, A., 2004. Combined effects of selected Penicillium mycotoxins on in vitro proliferation of porcine lymphocytes. Mycopathologia 158: 441-450.

Betina, V., E. Gasperíková and Nemec, P., 1969. Isolation of penicillic acid from Penicillium simplicissimum. Biologia (Bratislava) 24: 482-485.

Birch, A.J., Massey-Westropp, R.A. and Moye, C.J., 1955. Studies in relation to biosynthesis. VII. 2-Hydroxy-6-methyl-benzoic acid in Penicillium griseofulvum. Australian Journal of Chemistry 8: 539-544.

Birkinshaw, H., Bracken, A., Michael, S.E. and Raistrick, H., 1943. Patulin in the common cold. II. Biochemistry and chemistry. Lancet 1943: 625-631.

Birkinshaw, J.H. and Gowlland, A., 1962. Studies in the biochemistry of microorganisms 110. Production and biosynthesis of orsellinic acid by Penicillium madriti G. Smith. Biochemical Journal 84: 342-347.

Birkinshaw, J.H. and Raistrick, H., 1936. Studies in the biochemistry of mciroorganisms. LII. Isolation, properties and constitution of terrestric acid (ethylcarolic acid), a metabolic product of Penicillium terrestre Jensen. Biochemical Journal 30: 2194-2200.

Birkinshaw, J.H. and Samant, M.S., 1960. Studies in the biochemistry of microorganisms. 107. Metabolites of Penicillium viridicatum Westling: Viridicatic acid (ethylcarlosic acid). Biochemical Journal 74: 369-373.

Birkinshaw, J.H., Oxford, A.E. and Raistrick, H., 1936. Studies in the biochemistry of microorganisms. XLVIII. Penicillic acid, a metabolic product of Penicillium puberulum Bainier and Penicillium cyclopium Westling. Biochemical Journal 30: 394-411.

Bokhari, F.M. and Flannigan, B., 1996. Synthesis of penicillic acid and other metabolites by Penicillium aurantiogriseum in stored cereals and lentils. In: Sand, W. (ed.) Biodeterioration and biodegradation, Dachema Monographs 133, Dachema, Frankfurt, pp. 237-244.

Borkowska Opacka, B. and Escoula, L., 1977. Production de la patuline en milieu liquide par des moissisures appartenant aux genres: Aspergillus et Penicillium. Annales de Recherches Veterinaires 8: 129-133. 
Bosch, U. and Mirocha, C.J., 1992. Toxin production by Fusarium species from sugar beets and natural occurrence of zearalenone in beets and beet fibers. Applied and Environmental Microbiology 58: 3233-3239.

Bosch, U., Mirocha, C.J. and Wen, Y., 1992. Production of zearalenone, moniliformin and trichothecenes in intact sugar beets under laborarory conditions. Mycopathologia 119: 167-173.

Bourdiol, D., Escoula, L. and Salvayre, R., 1990. Effect of patulin on microbial activity of mouse peritoneal macrophages. Food and Chemical Toxicology 11: 617-624.

Boysen, M., Skouboe, P., Frisvad, J.C. and Rossen, L., 1996. Reclassification of the Penicillium roqueforti group into three species on the basis of molecular genetic and biochemical profiles. Microbiology-SGM 142: 541-549.

Brase, S., Encinas, A., Keck, J. and Nising, C.F., 2009. Chemistry and biology of mycotoxins and related fungal metabolites. Chemical Reviews 109: 3903-3990.

Bresler, G., Brizzio, S.B. and Vaamonde, G., 1995. Mycotoxin-producing potential of fungi isolated from amaranth seeds in Argentina. International Journal of Food Microbiology 25: 101-108.

Brian, P.W., Elson, G.W. and Lowe, D., 1956. Production of patulin in apple fruits by Penicillium expansum. Nature 178: 263.

Bridge, P.D., Hawksworth, D.L., Kozakiewicz, Z., Onions, A.H.S, Paterson, R.R.M., Sackin, M.J. and Sneath, P.H.A., 1989. A reappraisal of the terverticillate penicillia using biochemical, physiological and morphological features. I. Numerical taxonomy. Journal of General Microbiology 135: 2941-2966.

Bu'Lock, J.D. and Ryan, A.J., 1958. The biogenesis of patulin. Proceedings of the Chemical Society 1958: 222-223.

Burgess, L.W., 2014. McAlpine memorial lecture - a love affair with Fusarium. Australasian Plant Pathology 43: 359-368.

Burka, L.T., Doran, J. and Wilson, B.J., 1982. Enzyme inhibition and the toxic action of moniliformin and other vinylogous $\alpha$-ketoacids. Biochemical Pharmacology 31: 79-84.

Burmeister, H.R., Ciegler, A. and Vesonder, R.F., 1979. Moniliformin, a metabolite of Fusarium moniliforme NRRL 6322: purification and toxicity. Applied and Environmental Microbiology 37: 11-13.

Burton, H.S. and Pausacker, B.F., 1947. Unpublished. Cited by: Abraham, E.P. and Florey, H.W. 1949. Substances produced by fungi imperfecti and ascomycetes. In: Florey, H.W., Chain, E., Heatley, N.G., Jennings, M.A., Sanders, A.G., Abraham, E.P. and Florey, M.E. (eds.) Antibiotics. Vol. 1. Oxford University Press, London, UK, pp. 273-283.

Burton, H.S., 1949. Antibiotics from Penicillia. British Journal of Experimental Pathology 30: 151-158.

Cakmakci, S., Cetin, B., Gurses, M., Dagdemir, E. and Hayaloglu, A.A., 2012. Morphological, molecular, and mycotoxigenic identification of dominant filamentous fungi from moldy civil cheese. J Food Prot. 75: 2045-2049.

Cakmakci, S., Gurses, M., Hayaloglu, A.A., Cetin, B., Sekerci, P. and Dagdemir, E., 2015. Mycotoxin production capability of Penicillium roqueforti in strains isolated from mould-ripenes traditional Turkish civil cheese. Food Additives \& Contaminants: Part A: Chemistry, Analysis, Control, Exposure \& Risk Assessment 32: 245-249.
Casquete, R., Rodríguez, A., Hernández, A., Martín, A., Bartolomé, T., Córdoba, J.J. and Córdoba, M.G., 2017. Occurrence of toxigenic fungi and mycotoxins during smoked paprika production. Journal of Food Protection 80: 2068-2077.

Chain, E.H., Florey, W. and Jennings, M.A., 1942. An antibacterial substance produced by Penicillium claviforme. British Journal of Experimental Pathology 23: 202-205.

Chan, P.K. and Hayes, A.W., 1981. Hepatotoxicity of the mycotoxin penicillic acid - a pharmacokinetics consideration. Journal of the American Oil Chemists' Society 58: 1017-1022.

Chełkowski, J. and Golinski, P., 1983. Mycotoxins in cereal grain. 7. A simple method to assay mycotoxin potential of cereal grain and cereal products. Die Nahrung 27: 305-310.

Chełkowski, J., Golinski, P. and Wiewiorowska, M., 1987. Mycotoxins in cereal grain. 12. Contamination with ochratoxin A and penicillic acid as indicator of improper storage of cereal grain. Die Nahrung 31: 81-84.

Chełkowski, J., Trojanowska, K. and Wiewiorowska, M., 1983. Mycotoxins in cereal grain. 8. Microbiological evaluation of cereal grain quality, connected with mycotoxins occurrence. Die Nahrung 27: 311-318.

Chen, A.J., Frisvad, J.C., Sun, B.D., Varga, J., Kocsubé, S., Dijksterhuis, J., Kim, D.H., Hong, S.B., Houbraken, J. and Samson, R.A., 2016b. Aspergillus section Nidulantes (formerly Emericella). Polyphasic taxonomy, chemistry and biology. Studies in Mycology 84: 1-118.

Chen, A.J., Hubka, V., Frisvad, J.C., Visagie, C.M., Houbraken, J., Meijer, M., Varga, J., Rasine, D., Jurjević, Ž, Kubátová, A., Sklenář, F. and Samson, R.A., 2017. Polyphasic taxonomy of Aspergillus section Aspergillus (formerly Eurotium) and its occurrence in indoor environment and food. Studies in Mycology 88: 37-135.

Chen, A.J., Varga, J., Frisvad, J.C., Jiang, X.Z. and Samson, R.A., 2016a. Polyphasic taxonomy of Aspergillus section Cervini. Studies in Mycology 85: 65-89.

Chen, L.Y., Tain, X.L. and Yang, B., 1990. A study on the inhibition of rat myocardium gluthatione peroxidase and glutathione reductase by moniliformin. Mycopathologia 110: 119-124.

Chunmei, J., Junling, S., Qi'an, H. and Yanlin, L., 2013. Occurrence of toxin-producing fungi in intact and rotten table and wine grapes and related influencing factors. Food Control 31: 5-13.

Ciegler, A. and Kurtzman, C.P., 1970. Penicillic acid production by blue-eye fungi on various agricultural commodities. Journal of Applied Microbiology 20: 761-764.

Ciegler, A., 1972. Bioproduction of ochratoxin A and penicillic acid by members of the Aspergillus ochraceus group. Canadian Journal of Microbiology 18: 631-636.

Ciegler, A., 1977. Patulin. In: Rodricks, J.V., Hesseltine, C.W. and Mehlman, M.A. (eds.) Mycotoxins in human and animal health. Pathotox Publishers, Park Forest South, IL, USA, pp. 609-624.

Ciegler, A., Beckwith, A.C. and Jackson, L.K., 1976. Teratogenicity of patulin and patulin adducts formed with cysteine. Applied and Environmental Microbiology 31: 644-667.

Ciegler, A., Detroy, R.W. and Lillehoj, E.B., 1971. Patulin, penicillic acid and other carcinogenic lactones. In: Ciegler, A., Kadis, S. and Ajl, S.J. (eds.) Microbial toxins. Vol. VI. Fungal toxins. Academic Press, New York, NY, USA, pp. 404-434. 
Ciegler, A., Fennell, D.I., Sansing, G.A., Detroy, R.W. and Bennett, G.A., 1973. Mycotoxin producing strains of Penicillium viridicatum: Classification into subgroups. Journal of Applied Microbiology 26: 271-278.

Ciegler, A., Mintzlaff, H.J., Machnick, W. and Leistner, L., 1972. Untersuchungen über das Toxinbildungsvermögen von Rohwürsten isolierter Schimmelpilze der Gattung Penicillium. Fleischwirtschaft 52: 1311-1314.

Ciegler, A., Mintzlaff, H.-J., Weisleder, D. and Leistner, L., 1972. Potential production and detoxification of penicillic acid in mildfermented sausage (salami). Journal of Applied Microbiology 24: 114-119.

Clutterbuck, P.W., Oxford, A.E., Raistrick, H. and Smith, G., 1932. Studies in the biochemistry of microorganisms XXIV. The metabolic products of the Penicillium brevicompactum series. Biochemistry Journal 26: 1441-1458.

Cole, R.J. and Cox, R.H., 1981. Handbook of toxic fungal metabolites. Academic Press, New York, NY, USA.

Cole, R.J., Kirksey, J.W., Cutler, H.G., Doubnik, B.L. and Peckham, J.C., 1973. Toxin from Fusarium moniliforme: effect on plants and animals. Science 179: 1324-1326.

Couch, B.C. and Kohn, L.M., 2002. A multilocus gene genealogy concordant with host preference indicates segregation of a new species, Magnaporthe oryzae, from M. grisea. Mycologia 94: 683693.

Couch, R.D. and Gaucher, G.M., 2004. Rational elimination of Aspergillus terreus sulochrin production. Journal of Biotechnology 108: 171-177.

Da Silva, J.V., Fill, T.P., Da Silva, B.F. and Rodriguez-Fo, E., 2013. Diclavatol and tetronic acids from Penicillium griseoroseum. Natural Product Research 27: 9-16.

Delgado, S., Núñez, F., Sánchez, B., Bermúdez, E. and Rodríguez, J.M., 2011. Toxinogenic microorganisms in medicinal plants used for ritual protection of infants. Food Research International 44: 304-309.

Detroy, R.W. and Still, P.E., 1975. Patulin inhibition of mycovirus replication in Penicillium stoloniferum. Journal of General Microbiology 92: 167-174.

Devaraj, H., Suseela, R.E. and Devaraj, N., 1986. Patulin toxicosis in chicks. Current Science 55: 998-999.

Dickens, F. and Jones, H.E.H., 1961. Carcinogenic activity of a series of reactive lactones and related substances. British Journal of Cancer 15: $85-100$

Dickens, F. and Jones, H.E.H., 1963. Further studies on the carcinogenic and growth-inhibitory activity of a series of reactive lactones and related substances. British Journal of Cancer 17: 100-108.

Dickens, F. and Jones, H.E.H., 1965. Further studies on the carcinogenic action of certain lactones and related substances in the rat and mouse. British Journal of Cancer 19: 392-403.

Dimroth, P., Ringelmann, E. and Lynen, F., 1976. 6-Methylsalicylic acid synthetase from Penicillium patulum. European Journal of Biochemistry 68: 591-596.

Dombrinck-Kurtzman, M.A., 2007. The sequence of the isoepoxydon dehydrogenase genes of the patulin biosynthesis pathway in Penicillium species. Antonie van Leeuwenhoek 91: 179-189.
Dombrink-Kurtzman, M.A. and Blackburn, J.A., 2005. Evaluation of several culture media for production of patulin by Penicillium species. International Journal of Food Microbiology 98: 241-248.

Dombrink-Kurtzman, M.A. and McGovern, A.E., 2007. Speciesspecific identification of Penicillium linked to patulin contamination. Journal of Food Protection 70: 2646-2650.

Dowd, P.F., 1989. Toxicity of naturally occurring levels of the Penicillium mycotoxins citrinin, ochratoxin A, and penicillic acid to the corn earwormm Heliothis zea, and the fall armyworm, Spodoptera frugiperda (Lepidoptera: Noctuidae). Environmental Entomology 18: 24-29.

Draughon, F.A. and Ayers, J.C., 1980. Insecticide inhibition of growth and patulin production in Penicillium expansum, Penicilllium urticae, Aspergillus clavatus, Aspergillus terreus, and Byssochlamys nivea. Journal of Agricultural and Food Chemistry 28: 1115-1117.

Drusch, S. and Ragab, W., 2003. Mycotoxins in fruits, fruit juices, and dried fruits. Journal of Food Protection 66: 1514-1527.

Edwards, R.L., Maitland, D.J., Oliver, C.L., Pacey, M.S., Shileds, L. and Whalley, A.J.S., 1999. Metabolites of the higher fungi. Part 31. Longianone, a $\mathrm{C}_{7} \mathrm{H}_{6} \mathrm{O}_{4}$ spiro bicyclic lactone from the fungus Xylaria longiana. Journal of the Chemical Society, Perkin Transactions 1: 715-719.

Efimenko, O.M. and Yakimov, P.A., 1960. Antibiotic from Penicillium cyclopium. Trudy Leningradskii Khimiko-Farmatsevticheskii Institut, pp. 88-92; Chemical Abstracts 55: 21470f, 1961.

El-Banna, A.A., Pitt, J.I. and Leistner, L., 1987. Production of mycotoxins by Penicillium species. System. Journal of Applied Microbiology 10: 42-46.

Eldridge, J.A., Jaiswal, D.K., Jones, J.R. and Thomas, R., 1977. Tritium nuclear magnetic resonance spectroscopy. Part 7. New information of the tritium distibution in biosynthetically labelled penicillic acid. Journal of the Chemical Society Perkin Transactions I: 1080-1083.

Ellis, J.R., Norstadt, F.A. and McCalla, T.M., 1977. Patulin effects wheat plants in field treatments. Plant Soil 47: 679-686.

El-Samawaty, A.M.A., Abd El-Rahim, M.A., Moslem, M.A., Yassin, M.A., Sayed, S.R.M., El-Shikh, M.S., 2013. Control of grape blue molding penicillia by Allium sativum. Journal of Pure and Applied Microbiology 7: 1047-1053.

El-Shanawany, A.A., Moustafa, M.E. and Barakat, A., 2005. Fungal populations and mycotoxins in silage in Assiut and Sohag governates in Egypt, with a special reference to characteristic Aspergillus toxins. Mycopathologia 159: 281-289.

Engel, G. and Teuber, M., 1984. Patulin and other small lactones. In: Betina, V. (ed.) Mycotoxins - production, isolation, separation, and purification. Elsevier, Amsterdam, the Netherlands, pp. 291-298.

Erdogan, A., Gurses, M. and Sert, S., 2003. Isolation of moulds capable of producing mycotoxins from blue mouldy Tulum cheeses produced in Turkey. International Journal of Food Microbiology 85: 83-85.

Escoula, L., 1974. Moisissures toxinogènes des fourrages ensilés. I. Présence de patuline dans les fronts de coupe d'ensilages. Annales de Recherches Veterinaires 5: 423-432.

Escoula, L., 1975. Toxinogenic moulds in silage IV. Patulin production in liquid medium using fungus species isolated from silage. Annales de Recherches Veterinaires 6: 303-310. 
Escoula, L., Moore, J. and Baradat, C., 1977. The toxins of Byssochlamys nivea. Part I. Acute toxicity of patulin in adult rats and mice. Annales de Recherches Veterinaires 8: 41-49.

Escoula, L., Thompsen, M., Bourdoiol, M., Pipy, B., Peuriere, S. and Roubinet, S., 1988. Patulin immunotoxicology: effect on phagocyte activation and cellular and hunoral immune system of mice and rabbits. International Journal of Immunopharmacology 10: 983-989.

European Union, 2003. Commission regulation (EC) No. 1425/2003 of 11 August 2003 amending Regulation (EC) No 466/2001 as regards patulin. Official Journal of the European Union L 203/13.

Ezzat, S.M., El-Sayed, A.E., Abou El-Hawa, M.I., Ismaiel, A.S., 2007. Morphological and ultrastructural studies for the biological action of penicillic acid on some bacterial species. Research Journal of Microbiology 2: 303-314.

Filtenborg, O., Frisvad, J.C. and Thrane, U., 1996. Moulds in food spoilage. International Journal of Food Microbiology 33: 85-102.

Florey, H.W., Chain, E., Heatley, N.G., Jennings, M.A., Sanders, A.G., Abraham, E.P. and Florey, M.E., 1949. Antibiotics. Vol. 1. Oxford University Press, Oxford, UK, pp. 273-283.

Florey, H.W., Jennings, M.A. and Philpot, F.J., 1944. Claviformin from Aspergillus giganteus Wehm. Nature 153: 139.

Forrester, P.I. and Gaucher, G.M., 1972a. Conversion of 6-methylsalicylic acid into patulin by Penicillium urticae. Biochemistry 11: 1102-1107.

Forrester, P.I. and Gaucher, G.M., 1972b. m-Hydroxybenzyl alcohol dehydrogenase from Penicillium urticae. Biochemistry 11: 1108-1114.

Fotso, J., Leslie, J.F. and Smith, J.S., 2002. Production of beauvericin, moniliformin, fusaproliferin, and fumonisin $\mathrm{B}_{1}, \mathrm{~B}_{2}$, and $\mathrm{B}_{3}$ by fifteen ex-type strains of Fusarium species. Applied and Environmental Microbiology 68: 5195-5197.

Franck, B. and Breipohl, G., 1984. Biosynthesis of moniliformin, a fungal toxin with cyclobutanedione structure. Angewandte Chemie International Edition 23: 996-998.

Frank, H.K., 1972. Das Mykotoxinprodukten bei Lebensmitteln und Getrinken. Zentralblatt für Bakteriologie und Hygiene. 1. Abt. Originale B 159: 324-334.

Frank, H.K., 1977. Occurrence of patulin in fruits and vegetables. Annales de la Nutrition et de L'Alimentation 31: 459-465.

Frisvad, J.C., 1981. Physiological criteria and mycotoxin production as aids in identification of common asymmetric Penicillia. Applied and Environmental Microbiology 41: 568-579.

Frisvad, J.C., 1989. The connection between the penicillia and aspergilli and mycotoxins with special emphasis on misidentified isolates. Archives of Environmental Contamination and Toxicology 18: 452-467.

Frisvad, J.C., 2015. Taxonomy, chemodiversity, and chemoconsistency of Aspergillus, Penicillium, and Talaromyces species. Frontiers in Microbiology 5: 773.

Frisvad, J.C. and Filtenborg, O., 1983. Classification of terverticillate penicillia based on profiles of mycotoxins and other secondary metabolites. Applied and Environmental Microbiology 46: 1301-1310.

Frisvad, J.C. and Filtenborg, O., 1989. Terverticillate Penicillia: chemotaxonomy and mycotoxin production. Mycologia 81: 837-861.
Frisvad, J.C. and Filtenborg, O., 1990. Revision of Penicillium subgenus Furcatum based on secondary metabolites and conventional characters. In: Samson, R.A. and Pitt, J.I. (eds.) Modern concepts in Penicillium and Aspergillus classification. Plenum Press, New York, NY, USA, pp. 159-170.

Frisvad, J.C. and Larsen, T.O., 2015. Chemodiversity in the genus Aspergillus. Journal of Applied Microbiology Biotechnology 99: 7859-7877.

Frisvad, J.C. and Samson, R.A., 2000. Neopetromyces gen nov. and an overview of teleomorphs of Aspergillus subg. Circumdati. Studies in Mycology 45: 201-207.

Frisvad, J.C. and Samson, R.A., 2004. Polyphasic taxonomy of Penicillium subgenus Penicillium. A guide to identification of the food and air-borne terverticillate Penicillia and their mycotoxins. Studies in Mycology 49: 1-173.

Frisvad, J.C., Filtenborg, O. and Wicklow, D.T., 1987. Terverticillate Penicillia isolated from underground seed caches and cheek pouches of banner-tailed kangaroo rats (Dipodomys spectabilis). Canadian Journal of Botany 65: 765-773.

Frisvad, J.C., Frank, J.M., Houbraken, J.A.M.P., Kuijpers, A.F.A. and Samson, R.A., 2004a. New ochratoxin A producing species in Aspergillus section Circumdati. Studies in Mycology 50: 23-43.

Frisvad, J.C., Seifert, K.A., Samson, R.A. and Mills, J.T., 1994. Penicillium tricolor, a new mold species from Canadian wheat. Canadian Journal of Botany 72: 933-939.

Frisvad, J.C., Smedsgaard, J., Larsen, T.O. and Samson, R.A., 2004. Mycotoxins, drugs and other extrolites produced by species in Penicillium subgenus Penicillium. Studies in Mycology 49: 201-241.

Frisvad, J.C., Smedsgaard, J., Larsen, T.O. and Samson, R.A., 2004b. Mycotoxins, drugs and other extrolites produced by species in Penicillium subgenus Penicillium. Studies in Mycology 49: 201-242.

Fung, F. and Clark, R.F., 2004. Health effetcs of mycotoxins: a toxicological overview. Journal of Toxicology - Clinical Toxicology 42: 217-234.

Gallo, A., Giuberti, G., Frisvad, J.C., Bertuzzi, T. and Nielsen, K.F., 2015. Review on mycotoxin issues in ruminants: occurrence in forages, effects of mycotoxin ingestion on health status and animal performance and practical strategies to counteract their negative effect. Toxins 7: 3057-3111.

Garza, S., Canela, R., Vinas, I. and Sanchis, V., 1993. Effects of potassium sorbate on growth and penicillic acid production by Aspergillus ochraceus and Penicillium aurantiogriseum. Zentralblatt fur Mikrobiologie 148: 343-350.

Gathercole, P.S., Thiel, P.G. and Hofmeyr, J.H.S., 1986. Inhibition of pyruvate dehydrogenase complec by moniliformin. Biochemistry Journal 233: 719-723.

Gaucher, G.M., 1979. Mycotoxins - their biosynthesis in fungi: patulin and related carcinogenic lactones. Journal of Food Protection 42: 810-814.

Gedek, B., Bauer, J. and Schreiber, H., 1981. Mycotoxin production of silage deteriorating molds. Wiener Tierärztliche Monatsschrift 68: 299-301. 
Geiser, D.M., Aoki, T., Bacon, C.W., Baker, S.E., Bhattacharyya, M.K., Brandt, M.E., Brown, D.W., Burgess, L.W., Chulze, S., Coleman, J.J., Correll, J.C., Covert, S.F., Crous, P.W., Cuomo, C.A., De Hoog, G.S., Di Pietro, A., Elmer, W.H., Epstein, L., Frandsen, R.J.N., Freeman, S., Gagkaeva, T., Glenn, A.E., Gordon, T.R., Gregory, N.F., HammondKosack, K.E., Hanson, L.E., Del Mar Jímenez-Gasco, M., Kang, S., Kistler, H.C., Kuldau, G.A., Leslie, J.F., Logrieco, A., Lu, G., Lysøe, E., Ma, L.-J., McCormick, S.P., Mi gheli, Q., Moretti, A., Munaut, F., O'Donnell, K., Pfenning, L., Ploetz, R. C., Proctor, R.H., Rehner, S.A., Robert, V.A.R.G., Rooney, A.P., Bin Salleh, B., Scandiani, M.M., Scauflaire, J., Short, D.P.G., Steenkamp, E., Suga, H., Summerell, B.A., Sutton, D.A., Thrane, U., Trail, F., Van Diepeningen, A., VanEtten, H.D., Viljoen, A., Waalwijk, C., Ward, T.J., Wingfield, M.J., Xu, J.R., Yang, X.-B., Yli-Mattila, T. and Zhang, N., 2013. One fungus, one name: defining the genus Fusarium in a scientifically robust way that preserves longstanding use. Phytopathology 103: 400-408.

Geiger, M., Guitton, Y., Vansteelandt, M., Kerzaon, I., Blanchet, E., Robiou du Pont, T., Frisvad, J., Hess, P., Pouchus, Y.F. and Grovel, O., 2013. Cytotoxicity and mycotoxin production of shellfish-derived Penicillium spp., a risk for shellfish consumers. Letters in Applied Microbiology 57: 385-392.

Geiger, W.B. and Conn, J.E., 1945. The mechanism of the antibiotic action of clavacin and penicillic acid. Journal of the American Chemical Society 67: 112-116.

Gerlach, W. and Nirenberg, H.I., 1982. The genus Fusarium - a pictorial atlas. Biologische Bundesanstalt für Land- und Forstwirtschaft. Paul Parey, Berlin-Dahlem, Germany.

Ghadevaru, G., 2013. In vitro evaluation of toxin binding efficacy for aflatoxin B1, ochratoxin A, citrinin, zearalenone, T2 toxin, penicillic acid and fumonisin in brouiler chickens. Journal of Veterinary Pharmacology and Therapeutics 35, Suppl. 3: 50.

Ghisalberti, E.L., Hargraves, J.R., Skelton, B.W. and White, A.H., 2000. New patulin derivatives. Australian Journal of Chemistry 53: 995.997.

Giarman, N.J., 1948. Antibiotic lactones and synthetic analogs. 1. Cardiotoxin effects on the isolated frog heart. J. Pharmacol. Exp. Therap. 94: 232-243.

Gill-Carey, D.E., 1949. The nature of some antibiotics from aspergilli. British Journal of Experimental Pathology 30: 119-123.

Gilliver, K., 1946. The inhibitory action of antibiotics on plant pathogenic bacteria and fungi. Annals of Botany 10: 271-282.

Giridhar, P. and Reddy, S.M., 1998. The effect of polyamine biosynthesis inhibitors on mycelial growth and mycotoxin production by Aspergillus terreus. National Academy Science Letters (India) 21: 5-8.

Girisham, S. and Reddy, S.M., 1986a. Interaction of different seedborne fungi of pearl millet (Pennisetum americanum) and its effect on patulin production by Aspergillus terreus. Current Science 55: 730-732.

Girisham, S. and Reddy, S.M., 1986b. Efficacy of volatile compounds and food preservatives in the control of growth and patulin production by Aspergillus terreus, National Academy Science Letters (India) 9: 373-374.

Gorbach, G. and Friederick, W., 1949. Beitrage zur Kentnis der Penicillinsäure. Oesterreichische Chemiker Zeitung 50: 93-97.
Goss, R.J.M., Fuchser, J. and O'Hagan, D., 1999. Biosynthesis of longianone from Xylaria longiana: a metabolite with a biosynthetic relationship to patulin. Chemical Communications 1999: 2255-2256. Grabsch, C., Wichmann, G., Loffhagen, N., Herbarth, O. and Müller, A., 2006. Cytotoxicity asessment of gliotoxin and penicillic acid in Tetrahymena pyriformis. Environmental Toxicology 21: 111-117.

Gruber-Dorninger, C., Novak, B., Nagl, V. and Berthiller, F., 2017. Emerging mycotoxins: beyond traditionally determined food contaminants. Journal of Agricultural and Food Chemistry 65: 7052-7070.

Gutarowska, B., Sulyok, M. and Krska, R., 2010. A study of the toxicity of moulds isolated from dwellings. Indoor and Built Environment 19: 668-675.

Gye, W.E., 1943. Patulin in the common cold. III. Preliminary trial in the common cold. Lancet 1943: 630-631.

Hallas-Møller, M., Nielsen, K.F. and Frisvad, J.C., 2016. Production of the Fusarium mycotoxin moniliformin by Penicillium melanoconidium. Journal of Agricultural and Food Chemistry 64: 4505-4510.

Harwig, J., Chen, Y.-K., Kennedy, B.P.C. and Scott, P.M., 1973. Occurrence of patulin and patulin-producing strains of Penicillium expansum in natural rots of apple in Canada. Canadian Institute of Food Science and Technology Journal 6: 22-25.

Hayes, A.W., Phillips, T.D., Williams, W.L. and Ciegler, A., 1979. Acute toxicity of patulin in mice and rats. Toxicology 13: 91-100.

He, J., Wijeratne, E.M.K., Bashyal, B.P., Zhan, J., Seliga, C.J., Liu, M.X., Pierson, E.E., Pierson III, L.S., VenEtten, H.D. and Gunatilaka, A.A.L., 2004. Cytotoxic and other metabolites of Aspergillus inhabiting the rhizosphere of Sonoran desert plants. Journal of Natural Products 67: 1985-1991.

Herrare, M., Van Dam, R., Spanjer, M., De Stoppelaar, J., Mol, H., De Nijs, M. and López, P., 2017. Survey of moniliformin in wheat- and corn-based products using a straightforward analytical method. Mycotoxin Research 33: 333-341.

Herrick, J.A., 1945. Antifungal properties of clavacin. Proceedings of the Society for Experimental Biology and Medicine 59: 41-42.

Hopkins, J., 1993. The toxicological hazards of patulin. Food and Chemical Toxicology 31: 455-459.

Houbraken, J., Frisvad, J.C. and Samson, R.A., 2010. Sex in Penicillium series Roqueforti. IMA Fungus 1: 171-180.

Houbraken, J., López, C., Frisvad, J.C., Boekhout, T., Theelen, B., Molano, A.E.F. and Samson, R.A., 2011. Five new Penicillium species, P. aracuaraense, P. elleniae, P. penarojaense, P. vanderhammenii and $P$. wotroi, from Colombian leaf litter. International Journal of Systematic and Evolutionary Microbiology 61: 1462-1475.

Houbraken, J., Wang, L., Lee, H.B. and Frisvad, J.C., 2016. New sections in Penicillium containing novel species producing patulin, pyripyropens or other bioactive compounds. Persoonia 36: 299-314.

Hubka, V., Nováková, A., Kolarik, M., Jurjevics, Z. and Peterson, S.W., 2015. Revision of Aspergillus section Flavipedes: seven new species and proposal of section Jani sect. nov. Mycologia 107: 169-208.

Hubka, V., Nováková, A., Peterson, S.W., Frisvad, J.C., Sklenár, F., Matsusawa, T., Kubátová, A. and Kolařík, M., 2016. A reappraisal of Aspergillus section Nidulantes with descriptions of two new sterigmatocystin-producing species. Plant Systematics and Evolution 302: 1267-1299. 
Hussein, H.M., Baxter, M., Andrew, I.G. and Franich, R.A., 1991. Mycotoxin production by Fusarium species isolated from New Zealand maize fields. Mycopathologia 113: 35-40.

Ismaiel, A.A. and Papenbrock, J., 2015. Mycotoxins: producing fungi and mechanisms of phytotoxicity. Agriculture 5: 492-537.

Ismaiel, A.A., Bassyouni, R.H., Makel, Z. and Gabr, S.M., 2016. Detoxification of patulin by Kombucha tea culture. CyTA - Journal of Food 14: 271-279.

Jackson, L. and Dombrinck-Kurtzman, M.A., 2006. Patulin. In: Sapers, G.M., Gorny, J.R. and Yousef, A.E. (eds.) Microbiology of fruits and vegetables. CRC Press, Boca Raton, FL, USA, pp. 281-311.

Jímenez, M., Mateo, R., Querol, A., Huerta, T. and Hernández, E., 1991. Mycotoxins and mycotoxigenic moulds in nuts and sunflower seeds for human consumption. Mycopathologia 115: 121-127.

Jonsson, M., Atosuo, J., Jestoi, M., Nathanail, A.V., Kokkonen, U.M., Abttila, M., Koivisto, P., Lilius, E.-M. and Peltonern, K., 2015. Repeated does 28-day oral toxicity study of moniliformin in rats. Toxicology Letters 233: 38-44.

Jonsson, M., Jestoi, M., Nathanail, A.V., Kokkonen, U.-M., Anttila, M., Koivisto, P., Karhunen, P. and Peltonen, K., 2013. Application of OECD guideline 423 in assessing the acute oral toxicity of moniliformin. Food and Chemical Toxicology 53: 27-32.

Julca, I., Droby, S., Sela, N., Marcet-Houben, M. and Gabaldón, T., 2015. Contrasting genomic diversity in two closely related postharvest pathogens: Penicillium digitatum and Penicillium expansum. Genome Biology and Evolution 8: 218-227.

Jurjevic, Z., Kubátová, A., Lolarik, M. and Hubka, V., 2015. Taxonomy of Aspergillus section Petersonii sect. nov. encompassing indoor and soil-borne species wirth predominant tropical distribution. Plant Systematics and Evolution 301: 2441-2462.

Kamyar, M.R., Kouri, K., Rawnduzi, P., Studenic, C. and LemmensGruber, R., 2006. Effects of moniliformin in presence of cyclohexadepsipeptides on isolated mammalian tissue and cells. Toxicology in Vitro 20: 1284-1291.

Kang, S.W. and Kim, S.W., 2004. New antifungal activity of penicillic acid against Phytophthora species. Biotechnology Letters 26: 695698.

Kang, S.W., Park, C.H., Hong, S.I. and Kim, S.W., 2007. Production of penicillic acid by Aspergillus sclerotiorum CGF. Bioresource Technology 98: 191-197.

Karow, E.O. and Forster, J.W., 1944. An antibiotic substance from species of Gymnoascus and Penicillium. Science 99: 265-266.

Karow, E.O., Woodruff, H.B. and Forster, J.W., 1944. Penicillic acid from Aspergillus ochraceus, Penicillium thomi and Penicillium suavolens. Archives of Biochemistry 5: 279-282.

Kent, J. and Heatley, N.G., 1945. Antibiotics from moulds. Nature 156: 295-296.

Keromnes, J. and Thouvenot, D., 1985. Role of penicillic acid in the phytoxicity of Penicillium cyclopium and Penicillium canescens to germination of corn seeds. Applied and Environmental Microbiology 49: 660-663.

Khaddor, M., Saidi, R., Aidoun, A., Lamarti, A., Tantaoui-Eleraki, A., Ezziyyani, M., Castillo, M.-E.C. and Badoc, A., 2007. Antibacterial effects and toxigenesis of Penicillium aurantiogriseum and $P$. viridicatum. African Journal of Biotechnology 6: 2314-2318.
Kharchenko, S.M., 1970. Identification of antibiotics from Penicillia active against agents of mottled leaves and bunt fungi. Microbiologichny Zhurnal (Kiev) 32: 115-119.

Kildgaard, S., Mansson, M., Dosen, I., Klitgaard, A., Frisvad, J.C., Larsen, T.O. and Nielsen, K.F., 2014. Accurate dereplication of bioactive secondary metabolites from marine-derived fungi by UHPLC-DAD-QTOFMS and MS/HRMS library. Marine Drugs 12: 3681-3705.

Kimura, Y., Nakahara, S. and Fujioka, S., 1996. Aspyrone, a nematicidal compound isolated from the fungus Aspergillus melleus. Bioscience, Biotechnology, and Biochemistry 60: 1375-1376.

Kis, Z., Furger, P. and Sigg, H.P., 1969. Über die Isolierung von Pyrenophenol. Experientia 25: 123.

Klarić, M.S., Rašic, D. and Peraica, M., 2013. Deleterious effects of mycotoxin combinations involving ochratoxin A. Toxins 5: 19651987.

Kobayashi, H., Tsunoda, H. and Tatsuno, T., 1971. Recherches toxicologique sur les mycotoxines qui polluent de fourrages artificiel du porc. Chemical and Pharmaceutical Bulletin 19: 829-842.

Kocsubé, S., Perrone, G., Magistà, D., Houbraken, J., Varga, J., Szigeti G., Hubka, V., Hong, S.-B., Frisvad, J.C. and Samson, R.A., 2016. Aspergillus is monophyletic: evidence from multiple gene phylogenies and extrolite profiles. Studies in Mycology 85: 199-213.

Komagata, D., Fujita, S., Yamashita, N., Saito, S. and Morino, T., 1996. Novel neuritogenic activities of pseurotin A and penicillic acid. Journal of Antibiotics 49: 958-959.

Korzybski, T., Kowszyk-Gindifer, Z. and Kuryłowicz, W., 1967. Antibiotics. Origin, nature and properties. Pergamon Press, Oxford, UK.

Koteswara Rao, V., Shilpa, P., Girisham, S. and Reddy, S.M., 2011. Incidence of mycotoxigenic penicillia in feeds of Andhra Pradesh, India. International Journal of Biotechnology and Molecular Biology Research 2: 46-50.

Kovalsky, P., Kos, G., Nahrer, K., Schwab, C., Jenkins, T., Schatzmayr, G., Solyok, M. and Krska, R., 2016. Co-occurrence of regulated, masked and emerging mycotoxins and secondary metabolites in finished feed and maize - an extensive survey. Toxins 8: 12.

Kriek, N.P.J., Marasas, W.F.O., Steyn, P.S., Van Rensburg, S.J. and Steyn, M., 1977. Toxicity of moniliformin-producing strain of Fusarium moniliforme var. subglutinans isolated from maize. Food and Cosmetics Toxicology 15: 579-587.

Kubena, L.F., Phillips, T.D., Witzel, D.A. and Heidelbaugh, N.D., 1984. Toxicity of ochratoxin A and penicillic acid to chicks. Bulletin of Environmental Contamination and Toxicology 32: 711-716.

Kuehn, H.H., 1958. A preliminary survey of the Gymnoascaceae. I. Mycologia 50: 417-439.

Kumar, C.G., Mongolla, P., Pombala, S., Kamle, A. and Joseph, J., 2011. Physicochemical characterization and antioxidant activity of melanin from a novel strain of Aspergillus bridgeri ICTF-201. Journal of Applied Microbiology 53: 350-358.

Kurtzman, C.P. and Ciegler, A., 1970. Mycotoxin from a blue-eyed mold of corn. Journal of Applied Microbiology 20: 204-207.

Laidou, I.A., Thanassoulopoulos, C.C. and Liakopoulou-Kyriakidis, M., 2001. Diffusion of patulin in the flesh of pears inoculated with four post-harvest pathogens. Journal of Phytopathology 149: 457-461. 
Larsen, J. and Olson, L.W., 1992. Mode of action of $\alpha, \beta$ unsaturated carbonyl-compounds. Journal of Phytopathology 135: 1-5.

Larsen, T.O., Frisvad, J.C., Ravn, G. and Skaaning, T., 1998. Mycotoxin production by Penicillium expansum on black currant and cherry juice. Food Additives and Contaminants 15: 671-675.

Lebed, E.S., Novikova, S.D. and Kuznetsov, V.D., 1978. Production of penicillic and 6-amino penicillanic acid by some Trichoderma species. Mikol Fitopatol 12: 103-106.

Lei, H.Y., He, Z.P., Yuan, H., Wu, J., Wen, L.X., Li, R.F., Zhang, M., Yuan, L.Y. and Yuan, Z.H., 2010. Generation and characterization of a monoclonal antibody to penicillic acid from Penicillium cyclopium. African Journal of Biotechnology 9: 3026-3031.

Leistner, L. and Eckardt, C., 1979. Vorkommen toxinogener Penicillien bei Fleischerzeugnisse. Fleischwirtschaft 59: 1892-1896.

Leistner, L. and Pitt, J.I., 1977. Miscellaneous Penicillium toxins. In: Rodricks, J.V., Hesseltine, C.W. and Mehlman, M.A. (eds.) Mycotoxins in human and animal health. Chem-Orbital, pp. 639-653.

Lesley J. and Summerell, B.A., 2016. The Fusarium laboratory manual. Blackwell Publishing, Ames, IA, USA.

Lew, H., Chelkowski, J., Pronczuk, P. and Edinger, W., 1996. Occurrence of the mycotoxin moniliformin in maize (Zea mays $\mathrm{L}$ ) ears infected by Fusarium subglutinans (Wollenw. and Reinking) Nelson et al. Food Additives \& Contaminants 13: 321-324.

Li, B., Zong, Y., Du, Z., Zhang, Z., Qin, G., Zhao, W. and Tian, S., 2015. Genomic characterization reveals insights into patulin biosynthesis and pathogenicity in Penicillium species. Molecular Plant-Microbe Interactions 28: 635-647.

Li, H.J., Cai, Y.T., Chen, Y.Y., Lam, C.K. and Lan, W.J., 2010. Metabolites of marine fungus Aspergillus sp. collected from soft coral Sarcophyton tortuosum. Chemical Research in Chinese Universities 26: 415-419.

Lillehoj, E.B., Milburn, M.S. and Ciegler, A., 1972. Control of Penicillium martensii development and penicillic acid production by atmosphereic gases and temperatures. Applied Microbiology 24: 198-201.

Lindenfelser, L.A. and Ciegler, A., 1977. Penicillic acid production in submerged culture. Applied and Environmental Microbiology 34: 553-556.

Logrieco, A. and Bottalico, A., 1988. Fusarium species of the Liseola section associated with stalk and ear rot of maize in southern Italy, and their ability to produce moniliformin. Transactions of the British Mycological Society 90: 215-219.

Logrieco, A., Altomare, C., Moretti, A. and Bottalico, A., 1992. Cultural and toxigenic variability in Fusarium acuminatum. Mycological Research 96: 518-523.

Logrieco, A., Moretti, A., Altomare, C., Bottalico, A. and Carbonell Torres, E., 1993. Occurrence and toxicity of Fusarium subglutinans from peruvian maize. Mycopathologia 122: 185-190.

Logrieco, A., Moretti, A., Ritieni, A., Bottalico, A. and Corda, P., 1995. Occurrence and toxigenicity of Fusarium proliferatum from preharvest maize ear rot, and associated mycotoxins, in Italy. Plant Disease 79: 727-731.
Lopez-Diaz, T.M. and Flannigan, B., 1997. Production of patulin and cytochalasin E by 4 strains of Aspergillus clavatus during malting of barley and wheat. International Journal of Food Microbiology 35: 129-136.

Lund, F. and Frisvad, J.C., 1994. Chemotaxonomy of Penicillium aurantiogriseum and related species. Mycological Research 98: 481-492.

Luque, M.I., Rodríguez, A., Casado, E., Asensio, M.A. and Córdoba, J.J., 2011. Development of a PCR protocol to detect patulin producing moulds in food products. Food Control 22: 1831-1838.

Lykakis, I.N., Zaravinos, I.-P., Raptis, C. and Stratakis, M., 2009. Divergent synthesis of the co-isolated mycotoxins longianone, isopatulin, and (Z)-ascladiol via furan oxidation. Journal of Organic Chemistry 74: 6339-6342.

MacGeorge, K.M. and Mantle, P.G., 1990. Nephrotoxicity of Penicillium aurantiogriseum and $P$. commune from an endemic nephropathy area of Yugoslavia. Mycopathologia 112: 139-145.

Maidana, L., Gerez, J.R., El Khoury, R., Pinho, F., Puel, O., Oswald, I.P., Bracarense, A.P.F.R.L., 2016. Effects of patulin and ascladiol on porcine intestinal mucosa: an ex vivo approach. Food and Chemical Toxicology 98: 189-194.

Malekinejad, H., Aghazadeh-Attari, J., Rezabakhsh, A., Sattari, M. and Ghasemsoltani, B., 2015. Neurotoxicity of mycotoxins produced in vitro by Penicillium roqueforti isolated from maize and grass silage. Human \& Experimental Toxicology 34: 997-1005.

Mansouri, S., Houbraken, J., Samson, R.A., Frisvad, J.C., Christensen, M., Tuthill, D., Koutaniemi, S., Hatakka, A. and Lankinen, P., 2013. A new Penicillium species efficiently producing inulinase. Antonie van Leeuwenhoek 103: 1343-1357.

Mantle, P.G., 1994. Reneal histopathological responses to nephrotoxic Penicillium aurantiogriseum in the rat during pregnancy, lactation and after weaning. Nephron 66: 903-998.

Mantle, P.G., McHugh, K.M. and Fincham, J.E., 2010. Contrasting nephropathic responses to oral administration of extract of cultured Penicillium polonicum in rat and primate. Toxins 2: 2083-2097.

Marasas, W.F.O., Nelson, P.E. and Toussoun, T.A., 1988. Reclassification of two important moniliformin-producing strains of Fusarium, NRRL 6022 and NRRL 6322. Mycologia 80: 407-410.

Marasas, W.F.O., Thiel, P.G., Rabie, C.J., Nelson, P.E. and Toussoun, T.A., 1986. Moniliformin production in Fusarium section Liseola. Mycologia 78: 242-247.

Marasas, W.F.O., Thiel, P.G., Sydenham, E.W., Rabie, C.J., Lübben, A. and Nelson, P.E., 1991. Toxicity and moniliformin production by four recently described species of Fusarium and two uncertain taxa. Mycopathologia 113: 191-197.

Martínez-Luis, S., González, M.C., Ulloa, M. and Mata, R., 2005. Phytotoxins from the fungus Malbranchea aurantiaca. Phytochemistry 66: 1012-1016.

Mayer, V.W. and Legator, M.S., 1969. Production of petite mutants of Saccharomyces cerevisiae by patulin. Journal of Agricultural and Food Chemistry 17: 454-456.

McKinley, E.R. and Carlton, W.W., 1980a. Patulin mycotoxicosis in the Syrian Hamster. Food and Cosmetics Toxicology 18: 173-179.

McKinley, E.R. and Carlton, W.W., 1980b. Patulin mycotoxicosis in Swiss ICR mice. Food and Cosmetics Toxicology 18: 181-187. 
McKinley, E.R. and Carlton, W.W., 1991. Patulin. In: Sharma, R.P. and Salunkhe, D.K. (eds.) Mycotoxins and phytoalexins. CRC Press, Boca Raton, FL, USA, pp. 191-236.

McKinley, E.R., Carlton, W.W. and Boon, G.D., 1982. Patulin mycotoxicosis in the rat: toxicology, pathology and clinical pathology. Food and Cosmetics Toxicology 20: 289-300.

Micco, C., Miraglia, M., Onori, R., Libanori, A., Brera, C., Montaovani, A. and Macri, C., 1989. Long-term administration of low doses of mycotoxins in poultry - sysnergistic effects of ochratoxin A and penicillic acid on residues and toxicity in broilers. In: Institut National de Recherche Agronomique (ed.) Agriculture, food chemistry and the consumer, vols 1 and 2: the consumer and food, analytical food chemistry and agricultural production, biotechnology and bioassays - impact of technology on food quality, food chemistry and quality assurance. $5^{\text {th }}$ European Conference on Food Chemistry: agriculture, food chemistry and the consumer. 27-29 September, 1989. Versailles, France, pp. 121-125.

Mikami, A., Okazawa, T., Sakai, N., Hanada, K. and Mizoue, K., 1996. A new derivative pintulin produced by Penicillium vulpinum F-4148. Taxonomy, isolation, physico-chemical properties, structure and biological properties. Journal of Antibiotics 49: 985-989.

Miljkovic, A., Pfohl-Leszkowicz, A., Drobrota, M. and Mantle, P.G., 2003. Comparative responses to mode of oral administration and dos of ochratoxin A or hephrotoxic extract of Penicillium polonicum in rats. Experimental and Toxicologic Pathology 54: 305-312.

Miller, J.D., Savard, M.E., Schaafma, A.E., Seifert, K.A. and Reid, L.M., 1995. Mycotoxin prioduction of Fusarium moniliforme and Fusarium proliferatum from Ontario and occurrence of fumonisin in the 1993 corn crop. Canadian Journal of Plant Pathology 17: 233-239.

Mills, J.T., Frisvad, J.C., Seifert, K.A. and Abramson, D., 1995a. Identification of nephrotoxic Penicillium species from cereal grains. Mycotoxin Research 11: 25-36.

Mills, J.T., Seifert, K.A., Frisvad, J.C. and Abramson, D., 1995b. Nephrotoxigenic Penicillium species occurring on farm-stored cereal grains in Western Canada. Mycopathologia 130: 23-28.

Mintzlaff, H.J., Ciegler, A. and Leistner, L., 1972. Potential mycotoxin problems in mould fermented sausages. Zeitschrift für LebensmittelUntersuchung und -Forschung 150: 133-137.

Mioso, R., Marante, F.T. and De Laguna, I.H.B., 2015. Penicillium roqueforti: a multifunctional cell factory of high value-added molecules. Journal of Applied Microbiology 118: 781-791.

Moake, M.M., Padilla-Zakour, O.I. and Worobo, R.W., 2005. Comprehensive review of patulin control methods in foods. Comprehensive Reviews in Food Science and Food Safety 4: 8-21.

Mohan, L., Collins, G., Maher, S., Walsch, E.G. Winter, D.C., O'Brian, P.J., Brayden, D.J. and Baird, A.W., 2012. The mycotoxin patulin increases colonic epithelial permeability in vitro. Food and Chemical Toxicology 50: 4097-4102.

Montenegro, T.G.C., Rodrigues, F.A.R., Jimenez, P.C., Angelim, A.L., Melo, V.M.M., Filho, E.R., De Oliveira, M. and Costa-Lotufo, L.V., 2012. Cytotoxic activity of fungal strains isolated from the Ascidian Eudistoma vannamei. Chemistry \& Biodiversity 9: 2203-2209.

Morgavi, D.P., Boudra, H., Jouany, J.P. and Graviou, D., 2003. Prevention of patulin toxicity on rumen microbial fermentation by $\mathrm{SH}$-containing reducing agents. Journal of Agricultural and Food Chemistry 51: 6906-6910.
Mosbach, K., 1960. Die Biosynthese der Orsellinsäure und Penicillinsäure (1). Acta Chemica Scandinavica 14: 457-464.

Moslem, M., Abd-Elsalam, K., Yassin, M. and Bahkali, A., 2010. First morphomolecular identification of Penicillium griseofulvum and Penicillium aurantiogriseum toxicogenic isolates associated with blue mold on apple. Foodborne Pathogens and Disease 7: 857-861.

Moslem, M.A., Yassin, M.A., El-Samawaty, A.M.A., Abd El-Rahim, M.A., Sayed, S.R.M. and Amer, O.E., 2013. Mycotoxin-producing Penicillium species involved in apple blue mold rot. Journal of Pure and Applied Microbiology 7: 187-193.

Moslem, M.A., Yassin, M.A., El-Samawaty, A.R.M.A. and Sayed, S.R.M., 2011. New toxigenic Penicillium species associated with apple blue mold in Saudi Arabia. Fresenius Environmental Bulletin 20: 3194-3198.

Moubasher, A.H., Abdel-Kader, M.I.A. and El-Kady, I.A., 1978. Toxigenic fungi isolated from Roquefort cheese. Mycopathologia 66: 187-190.

Müller, H.M. and Amend, R., 1997. Formation and disappearance of mycophenolic acid, patulin, penicillic acid and PR toxin in maize silage inocuulated with Penicillium roqueforti. Archives of Animal Nutrition 50: 213-225.

Murnaghan, M.F., 1946. The pharmacology of penicillic acid. Journal of Pharmacology and Experimental Therapeutics 88: 119-132.

Myrchink, T.G., 1967. Production of patulin by a group of fungi Penicillium lapidosum Raper \& Fennell. Antibioki 12: 762-766.

Namikoshi, M., Negishi, R., Nagai, H., Dmitrenok, A. and Kobayashi, H., 2003. Three new chlorine containing antibiotics from a marinederived fungus Aspergillus ostianus collected in Pohnpei. Journal of Antibiotics 56: 755-761.

Nasser, L.A., 2008. Mycoflora, mycotoxins, bacteriological analysis and molecular assay of some bacterial species from coffee beans in Saudi Arabia. Bulletin of Pharmaceutical Sciences (Assiut University) 31: 345-373.

Nelson, P.E., Toussoun, T.A. and Marasas, W.F.O., 1983. Fusarium species. An illustrated manual for identification. The Pensylvania State University Press, University Park, PA, USA.

Neme, K. and Mohammed, A., 2017. Mycotoxin occurrence in grains and the role of postharvest management as a mitigation strategies. A review. Food Control 78: 412-425.

Nielsen, J.C., Grijseels, S., Prigent, S., Ji, B., Dainat, J., Nielsen, K.F., Frisvad, J.C., Workman, M. and Nielsen, J., 2017. Global analysis of secondary metabolite gene clusters in Penicillium species. Nature Microbiology 2, Article number: 17044.

Nielsen, K.F., Frisvad, J.C., Sumarah, M. and Miller, J.D., 2006. Production of metabolites from the Penicillium roqueforti complex. Journal of Agricultural and Food Chemistry 54: 3756-3763.

Nonaka, K., Chiba, T., Suga, T., Asami, Y., Iwatsuki, M., Msauma, R., Omura, S. and Shiomi, K., 2015. Coculnol, a new penicillic acid produced by a co-culture of Fusarium solani FKI-6853 and Talaromyces sp. FKI-65. Journal of Antibiotics 68: 530-532.

Northolt, M.D., Van Egmond, H.P. and Paulsch, W.E., 1978. Patulin production by some fungal species in relation to water activity and temperature. Journal of Food Protection 41: 885-890.

Northolt, M.D., Van Egmond, H.P. and Paulsch, W.E., 1979. Penicillic acid production by some fungal species in relation to water activity and temperature. Journal of Food Protection 42: 476-484. 
Nozawa, K., Udagawa, S., Nakajima, S. and Kawai, K., 1989. A dioxopiperazine derivative from Penicillium megasporum. Phytochemistry 28: 929-931.

Nukina, M., 1988. Terrestric acid as a phytotoxic metabolite from Pyricularia oryzae Cavara. Agricultural and Biological Chemistry 52: 2357-2358.

Obana, H., Kumeda, Y. and Nishimune, T., 1995a. Mutagenicity of 5,6-dihydropenicillic acid (DHPA) in Drosophila melanogaster and bacterial conversion of penicillic acid to DHPA. Journal of Food Protection 58: 1375-1378.

Obana, H., Kumeda, Y. and Nishimune, T., 1995b. Aspergillus ochraceus production of 5,6-dihydropenicillic acid in culture and foods. Journal of Food Protection 58: 519-523.

O’Brien, M., Nielsen, K.F., O’Kiely, P., Forristal, P.D., Fuller, H.T. and Frisvad, J.C., 2006. Mycotoxins and other secondary metabolites produced in vitro by Penicillium paneum Frisvad and Penicillium roqueforti Thom isolated from baled grass silage in Ireland. Journal of Agricultural and Food Chemistry 54: 9268-9276.

Oh, S., Chung, I., Paik, S. and Yu, S., 1998. Survey and control of the occurrence of mycotoxins from postharvest cereals. 1. Mycotoxins produced by Penicillium isolates from corn and wheat. Korean Journal of Plant Pathology 14: 700-704.

Oh, S.-Y., Cedergreen, N., Yiannikouris, A., Swamy, H.V.L.N. and Karrow, N.A., 2015. Assessing interactions of binary mixtures of Penicillium mycotoxins (PMs) by using a bovine macrophage cell line (BoMacs). Toxicology and Applied Pharmacology 318: 33-40.

Okeke, B., Seigle-Murandi, F., Steiman, R., Benoit-Guyod, J.-L. and Kaouadji, M., 1993. Identification of mycotoxin-producing fungal strains: a step in the isolation of compounds active against rice fungal diseases. Journal of Agricultural and Food Chemistry 41: 1731-1735.

Olivigni, F.J. and Bullerman, L.B., 1977. Simultaneous production of penicillic acid and patulin by a Penicillium species isolated from Cheddar cheese. Journal of Food Science 42: 1654-1658.

Olivigni, F.J. and Bullerman, L.B., 1978. Production of penicillic acid and patulin by an atypical Penicillum roqueforti isolate. Journal of Applied Microbiology 35: 435-438.

Overy, D.P. and Frisvad, J.C., 2003. New Penicillium species associated with bulbs and root vegetables. Systematic and Applied Microbiology 26: 631-639.

Overy, D.P., Valdez, J.G. and Frisvad, J.C., 2005. Revisions to the Penicillium ser. Corymbifera: agents responsible for the blue mould storage rot of various flower and vegetable bulbs. Canadian Journal of Botany 83: 1422-1433.

Oxford, A.E., Raistrick, H. and Smith, G., 1942. Antibacterial substances from moulds. Part II. Penicillic acid, a metabolic product of Penicillium puberulum Bainier and Penicillium cyclopium Westling. Chemistry \& Industry 61: 22-24.

Oyero, O.G. and Oyefolu, A.O.B., 2009. Fungal contamination of crude herbal remedies as a possible source of mycotoxin exposure in man. Asian Pacific Journal of Tropical Medicine 2: 328-343.

Pandiyan, V., Nayeem, M., Nanjappan, K. and Ramamurti, R., 1990. Penicillic acid as $\mathrm{Na}^{+}, \mathrm{K}^{+}$and $\mathrm{Ca}^{2+}$ channel blocker in isolated frog heart at toxic levels. Indian Journal of Experimental Biology 28: 295-296.
Paster, N., Huppeert, D. and Barkai-Golan, R., 1995. Production of patulin by different strains of Penicillium expansum in pear and apple cultivars stored at different temperatures and modified atmospheres. Food Additives \& Contaminants 12: 51-58.

Paterson, R.R.M., 2004. The isoepoxydon dehydrogenase gene of patulin biosynthesis in cultures and secondary metabolites as candidate PCR inhibitors. Mycological Research 108: 1431-1437.

Paterson, R.R.M., Kozakiewicz, Z., Locke, T., Brayford, D. and Jones, S.C.B., 2003. Novel use of isoepoxydon dehydrogenase gene probe of the patulin metabolic pathway and chromatography to test penicillia isolated from apple production systems for the potential to contaminate apple juice with patulin. Food Microbiology 20: 359-364.

Paterson, R.R.M., Simmonds, M.S.J. and Blaney, W.M., 1987. Mycopesticidal effects of characterized extracts of Penicillium isolates and purified secondary metabolites (including mycotoxins) on Drosophila melanogaster and Spodoptora littoralis. Journal of Invertebrate Pathology 50: 124-133.

Patterson, M.F. and Damoglou, A.D., 1985. Identification and potential toxicity of fungi isolated from mould spoiled foods. Record of Agricultural Research 33: 49-55.

Paucod, J.C., Krivobok, S. and Vidal, D., 1990. Immunotoxicity testing of T-2 and patulin on Balb/C mice. Acta Microbiologica Hungarica 37: 331-339.

Pazhavinel, N., Balachandran, C., Muralimanohar, B., Dhinakarraj, G., Balahrishnan, V., Kirubuharan, J.J. and Raja, A., 2015. Alleviate effect of gingerol on cell mediated and humoral immunuity and immune organs against penicillic acid mycotoxicosis in broiler chickens. International Journal of Life science and Pharma Research 5: L28-L34.

Peltonen, K., Jestoi, M. and Eriksen, G.S., 2010. Health effects of moniliformin a poorly understood Fusarium mycotoxin. World Mycotoxin Journal 3: 403-414.

Phainuphong, P., Rukachaisirikul, V., Tedpetch, K., Sukpondma, Y., Saithong, S., Phongpichit, S., Preedanon, S. and Sakayaroj, J., 2017. $\gamma$-butenolide and furanone derivatives from the soil-derived fungus Aspergillus sclerotiorum PSU-RSPG178. Phytochemistry 137: 165-173.

Pitt, J.I., 1979. The genus Penicillium and its teleomorphic states Eupenicillium and Talaromyces. Academic Press, London, UK.

Priest, J.W., 1989. Patulin biosynthesis - epoxydation of toluquinol and gentisyl alcohol by particulate preparations from Penicillium patulum. Biochemistry 28: 9192-9200.

Puel, O., Galtier, P. and Oswald, I.P., 2010. Biosynthesis and toxicological effects of patulin. Toxins 2: 613-631.

Puel, O., Tadrist, S., Delaforge, M., Oswald, I.P. and Lebrihi, A., 2007. The inability of Byssochlamys fulva to produce patulin is related to absence of 6-methylsalicylic acid synthase and isoepoxydon dehydrogenase genes. International Journal of Food Microbiology 115: 131-139.

Qi, S, Nong, S., Zhang, X. and Xu, X., 2015. Butenolide compounds for antifouling agent use in marine coatings. Faming Zhuanli Shenqing. CN 104356730 A 20150218 [patent]. 
Quintanilla, J.A., 1982. Cuatro nuevas especies de Penicillium aisladas en centeno: $P$. mariaecrucis, sp. nov., $P$. castellae, sp. nov., P. cieglerii, sp. nov., y P. smithii, sp. nov. Avances en Alimentación y Mejora Animal 23: 333-343.

Rabie, C.J., Lübben, A., Louw, A.I., Rathbone, E.B., Steyn, P.S. and Vleggaar, R., 1978. Moniliformin, a mycotoxin from Fusarium fusaroides. Journal of Agricultural and Food Chemistry 26: 375-379.

Rabie, C.J., Marasas, W.F.O., Thiel, P.G., Lübben, A. and Vleggaar, R., 1982. Moniliformin production and toxicity of different Fusarium species from Southern Africa. Applied and Environmental Microbiology 43: 517-521.

Raja, H.A., Miller, A.N., Pearce, C.J. and Oberlies, N.H., 2017. Fungal identification using molecular tools: a primer for the natural products research community. Journal of Natural Products 80: 756-770.

Raphael, R.A., 1947a. Synthesis of the antibiotic, penicillic acid. Nature 160: 261-262.

Raphael, R.A., 1947b. Compounds related to penicillic acid. Part. II. Synthesis of dihydropenicillic acid. J. Chem. Soc. 1947: 805-808.

Rasmussen, T.B., Skindersoe, M.E., Bjarnsholt, T., Phipps, R.K., Christensen, K.B., Jensen, P.O., Andersen, J.B., Koch, B., Larsen, T.O., Hentzer, M., Eberl, L., Hoiby, N. and Givskov, M., 2005. Identification and effects of quorum-sensing inhibitors produced by Penicillium species. Microbiology-SGM 151: 1325-1340.

Reddy, A.S. and Reddy, S.M., 1984. Evaluation of certain volatile compounds against Aspergillus terreus and patulin production. National Academy Science Letters (India) 7: 239-241.

Reddy, V.K. and Reddy, S.M., 1988. Biochemical changes and patulin and terreic acid production by Aspergillus terreus in different cultivars of maize (Zea mays Linn). Journal of Food Science and Technology 25: 247-248.

Reio, L., 1958. A method for the paper-chromatographic separation and identification of phenol derivates, mould metabolites and related compounds of biochemical interest, using a reference system. Journal of Chromatography 1: 338-373.

Rice, S.L., Beuchat, L.R. and Worthington, R.E., 1977. Patulin production by Byssochlamys spp. in fruit juices. Applied and Environmental Microbiology 34: 791-796.

Samadha, M.K. and Balachandran, C., 2008. Serum electrolyte changes in penicillic acid toxicosis. Indian Veterinary Journal 85: 248-250.

Samson, R.A., Houbraken, J., Varga, J. and Frisvad, J.C., 2009. Polyphasic taxonomy of the heat resistant ascomycete genus Byssochlamys and its Paecilomyces anamorphs. Persoonia 22: 14-27.

Samson, R.A., Hubka, V., Varga, J., Houbraken. J., Hong, S.B., Klaassen, C.H.W., Perrone, G., Seifert, K.A., Magistá, D. Visagie, C.M., Kocsubé, S., Szigeti, G., Yaguchi, T., Peterson, S.W. and Frisvad, J.C., 2017. Response to Pitt and Taylor 2016: Conservation of Aspergillus with $A$. niger as the conserved type is unnessesary and potentially disruptive. Taxon 66: 1439-1446.

Samson, R.A., Peterson, S.W., Frisvad, J.C. and Varga, J., 2011a. New species in Aspergillus section Terrei. Studies in Mycology 69: 39-55.

Samson, R.A., Varga, J., Meijer, M. and Frisvad, J.C., 2011b. New species in Aspergillus section Usti. Studies in Mycology 69: 81-97.
Samson, R.A., Visagie, C.M., Houbraken, J., Hong, S.-B., Hubka, V., Klaassen, C.H.W., Perrone, G., Seifert, K.A., Susca, A., Tanney, J.B., Varga, J., Kocsubé, S., Szigeti, G., Yaguchi, T. and Frisvad, J.C., 2014. Phylogeny, identification and nomenclature of the genus Aspergillus. Studies in Mycology 78: 141-173.

Sanders, A.G., 1946. Effect of some antibiotics on pathogenic fungi. Lancet 1946: 44-46.

Sanderson, P.G. and Spotts, R.A., 1995. Postharvest decay of winter pear and apple fruit caused by species of Penicillium. Phytopathology Journal 85: 103-110.

Sant'Ana, A.S., Simas, R.C., Almeida, C.A.A., Cabral, E.C., Rauber, R.H., Mallmann, C.A., Eberlin, M.N., Rosenthal, A. and Massaguer, P.R., 2010. Influence of package, type of apple juice and temperature on the production of patulin by Byssochlamys nivea and Byssochlamys fulva. International Journal of Food Microbiology 142: 156-163.

Sarmadha, M.K., Balachandran, C. and Manohar, B.M., 2008a. Haematological changes in penicillic acid mycotoxicosis in the broiler chicken. Indian Veterinary Journal 85: 246-247.

Scarpino, V., Reyneri, A., Vanara, F., Scopel, C., Causin, R. and Blandino, M., 2015. Relationship between European cork borer injury, Fusarium proliferatum and F. subglutinans and moniliformin contamination in maize. Field Crops Research 183: 69-78.

Scauflaire, J., Gourgue, M. and Munaut, F., 2011. Fusarium temperatum sp. nov. from maize, an emergent species closely related to Fusarium subglutinans. Mycologia 103: 586-597.

Schurman, B.T.M., Sallum, W.S.T. and Takahashi, J.A., 2010. Austin, dehydroaustin and other metabolites from Penicillium brasilianum. Quimica Nova 33: 1044-1046.

Schütt, F., Nirenberg, H. and Demi, G., 1998. Moniliformin production in the genus Fusarium. Mycotoxin Research 14: 35-40.

Scott, A.I., Kennedy, B. and Van Walbeek, W., 1972. Desoxypatulinic acid from a patulin-producing strain of Penicillium patulum. Experientia 28: 1252.

Scott, A.I., Phillips, G.T. and Kirscheis, U., 1971. Biosynthesis of polyketides. The synthesis of 6-methyl salicylic acid and triacetic acid lactone in Penicillium patulum. Bioorganic Chemistry 1: 380-399.

Scott, P.M., 1974. Patulin. In: Purchase, I.F.H. (ed.) Mycotoxins. Elsevier, Amsterdam, the Netherlands, pp. 383-403.

Scott, P.M., Abbas, H.K., Mirocha, C.J., Lawrence, G.A. and Weber, D., 1987. Formation of moniliformin by Fusarium sporotrichioides and Fusarium culmorum. Applied and Environmental Microbiology 53: 196-197.

Scurti, J.C., Codignola, A., Nobili, G. and Caputo, O., 1973. Un ceppo di Byssochlamys nivea Westl., isolata da insilato di mais integrale, producente patulina. Allionia 19: 39-42.

Seifert, K.A., Samson, R.A., Dewaard, J.R., Houbraken, J., Levesque, C.A., Moncalvo, J.M., Louiz-Seize. G. and Hebert P.D.N., 2007. Prospects of fungal identification using CO1 DNA barcodes, with Penicillium as a test case. Proceedings of the National Academy of Sciences of the USA 104: 3901-3906.

Sekeguchi, J. and Gaucher, G.M., 1978. Identification of phyllostine as an intermediate of the patulin pathway in Penicillium urticae. Biochemistry 17: 1785-1791.

Sekiguchi, J., 1983. The biosynthesis of the mycotoxin, patulin. Hakkokogaku Kaishi 61: 129-137 [In Japanese]. 
Sekiguchi, J., Gaucher, G.M. and Yamada, Y., 1979. Biosynthesis of patulin in Penicillium urticae: identification of isopatulin as a new intermediate. Tetrahedron Letters 20: 41-42.

Şenyuva, H.Z., Gilbert, J. and Öztürkoğlu, S., 2008. Rapid analysis of fungal cultures and figs for secondary metabolites by LC/TOF-MS. Analytica Chimica Acta 617: 97-106.

Sewram, V., Nieuwoudt, T.W., Marasas, W.F.O., Shephard, G.S. and Ritieni, A., 1999. Determination of the mycotoxin moniliformin in cultures of Fusarium subglutinans and in naturally contaminated maize by HPLC-atmospheric pressure chemical ionization mass spectrometry. Journal of Chromatography A 848: 185-191.

Sharma, D., Asrani, R.K., Ledoux, D.R., Jindal, N., Rottinghaus, G.E. and Gupta, V.K., 2008. Individual and combined effetcs of fumonisin B1 and moniliformin in clinicopathological and cell-mediated immune response in Japanese quail. Poultry Science 87: 1039-1051.

Sharma, R.P., 1993. Immunotoxicity of mycotoxins. Journal of Dairy Science 76: 892-897.

Shiono, Y., Murayama, T., Takahashi, K., Okada, K., Katohda, S. and Ikeda, M., 2005. Three oxygenated cyclohexanone derivatives produced by an endophytic fungus. Bioscience, Biotechnology, and Biochemistry 69: 287-292.

Simonart, P. and De Lathouwer, R., 1956. Formation de patuline par Penicillium griseofulvum Dierckx. Zentralblatt fur Bakteriologie, Parasitenkunde, Infektionskrankheiten und Hygiene Abt. II 110: 107-109.

Singh, J., 1967. Patulin. In: Gottlieb, D. and Shaw, P.D. (eds.) Antibiotics. Vol. 1. Springer Verlag, New York, NY, USA, pp. 621-630.

Sklenář, F., Jurjević, Ž., Zalar, P., Frisvad, J.C., Visagie, C., Kolařík, M., Houbraken, J., Chen, A.J. Yilmaz, N., Seifert, K.A., Coton, M., Deniel, F., Gunde-Cimerman, N. and Samson, R.A., Peterson, S.W. and Hubka, V., 2017. Phylogeny of xerophilic aspergilli (subgenus Aspergillus) and taxonomic revision of section Restricti. Studies in Mycology 88: 161-236.

Skóra, J., Sylyok, M., Otlewska, A. and Gutarowska, B., 2017. Toxinogenicity and cytotoxicity of Alternaria, Aspergillus and Penicillium moulds isolated from working environments. International Journal of Environmental Science and Technology 14: 595-608.

Snini, S.P., Tadriest, S., Lafitte, J., Jamin, E.L., Oswald, I.P. and Puel, O., 2014. The gene pat $G$ involved in the biosynthesis pathway of patulin, a food-borne mycotoxin, encodes a 6-methylsalicylic acid decarboxylase. International Journal of Food Microbiology 171: 77-83.

Snini, S.P., Tannous, J., Heuillard, P., Bailly, S., Lippi, Y., Zehraoui, E., Barreau, C., Oswald, I.P. and Puel, O., 2015. Patulin is a cultivardependent aggressiveness factor favouring the colonization of apples by Penicilium expansum. Molecular Plant Pathology 17: 920-930.

Sommer, N.F., Buchanan, J.R. and Fortlage, R.J., 1974. Production of patulin by Penicillium expansum. Journal of Applied Microbiology 28: 589-593.

Sonjak, S., Frisvad, J.C. and Gunde-Cimerman, N., 2005. Comparison of secondary metabolite production by Penicillium crustosum strains, isolated from Arctic and other various ecological niches. FEMS Microbiology Ecology 53: 51-60.

Sorenson, W.G. and Simpson, J., 1986. Toxicity of penicillic acid for rat alveolar macrophages in vitro. Environmental Research 41: 505-513.
Steiman, R., Seigle-Murandi, F., Sage, L. and Krivobok, S., 1989. Production of patulin by micromycetes. Mycopathologia 105: 129-133.

Stoev, S., QAnguelov, G., Pavlov, D. and Pirovski, L., 1999. Some antidotes and paraclinical investigations in experimental intoxication with ochratoxin A and penicillic acid in chicks. Veterinary Archives 69: 179-189.

Stoev, S.D. and Denev, S.A., 2013. Porcine/chicken or human nephropathy as a result of joint mycotoxins interaction. Toxins 5: 1503-1530.

Stoev, S.D., 2013. Food safety and increasing hazard of mycotoxin occurrence in foods and feeds. Critical Reviews in Food Science and Nutrition 53: 887-901.

Stoev, S.D., 2017. Balkan Endemic Nephropathy - still continuiing enigma, risk assessment and underestimated hazard of joint mycotoxin exposure of animals or humans. Chemico-Biological Interactions 261: 63-79.

Stoev, S.D., Dutton, M.F., Njobeh, P.B., Mosonik, J.S. and Steenkamp, P.A., 2010. Mycotoxic nephropathy in Bulgarian pigs and chickens: complex aetiology and similarity to Balkan Endemic Nephropathy. Food Additives and Contaminants Part A 27: 72-88.

Stoev, S.D., Vitanov, S., Anguelov, G., Petkova-Bocharova, T. and Creppy, E.E., 2001. Experimental mycotoxin nephropathy in pigs provoked by a diet containg ochratoxin A and penicillic acid. Veterinary Research Communications 25: 205-223.

Svendsen, A. and Frisvad, J.C., 1994. A chemotaxonomic study of the terverticillate penicillia based on high performance liquid chromatography of secondary metabolites. Mycological Research 98: 1317-1328.

Szebiotko, K., Chełkowski, J., Dopierala, G., Godlewska, B. and Radomyska, W., 1981. Mycotoxins in cereal grain.1. Ochratoxin, citrinin, sterigmatocystin, penicillic acid and toxigenic fungi in cereal grain. Die Nahrung 25: 415-421.

Tachibana, M., Matsui, C., Takeuchi, Y., Suzuki, E. and Umezawa, K., 2008. Inhibition of NF-kappa B activation by penicillic acid and dihydropenicillic acid isolated from fungi. Heterocycles 76: 1561-1569.

Takahashi, J.A., De Castro, M.C.M., Souza, G.G., Lucas, E.M.F., Bracarense, A.A.P., Abreau, L.M., Marriel, I.E., Oliveira, M.S., Floreano, M.B. and Oliveira, T.S., 2008. Isolation and screening of fungal species isolated from Brazilian cerrado soil for antibacterial activity against Escherichia coli, Staphylococcus aureus, Streptococcus pyogenes and Listeria monocytogenes. Journal de Mycologie Médicale 18: 198-204.

Tanenbaum, S.W. and Bassett, E.W., 1959. The biosynthesis of patulin. III. Evidence for a molecular rearrangement of the aromatic ring. Journal of Biological Chemistry 234: 1861-1866.

Tangni, E.K. and Pussemier, L., 2007. Ergosterol and myctoxins in grain dusts from fourteen Belgian cereal storages: a preliminary screening survey. Journal of the Science of Food and Agriculture 87: 1263-1270.

Tannous, J., El Khoury, R., Snini, S.P., Lippi, Y., El Khoury, A., Atoui, A., Lteif, R., Oswald, I.P. and Puel, O., 2014. Sequencing, physical organization and kinetic expression of the patulin biosynthetic gene cluster from Penicillium expansum. International Journal of Food Microbiology 189: 51-60. 
Thiel, P.G., 1978. A molecular mechanism for the toxic action of moniliformin, a mycotoxin produced by Fusarium moniliforme. Biochemical Pharmacology 27: 483-486.

Tseng, T.C., 1993. Mycotoxins produced by Fusarium spp. of Taiwan. Botanical Bulletin of Academia Sinica 34: 261-269.

Tsunoda, H., Kishi, K., Okubo, K., Tatsuno, T. and Ohtsubo, K., 1978. Morphology and culture of Penicillium ochraceum and P. carneolutescens in Penicillium. Proceedings of the Japanese Association of Mycotoxicology 5-6: 11-13.

Tuthill, D.E. and Frisvad, J.C., 2002. Eupenicillium bovifimosum, a new species from dry cow manure in Wyoming. Mycologia 94: 240-246.

Ueno, I., 1994. Toxicities of the mycotoxins produced by the fungi of Penicillium species. Mycotoxins 40: 15-17.

Uhlig, S., Torp, M., Jarp, J., Parich, A., Gutlep, A.C. and Krska, R., 2004. Moniliformin in Norwegean grain. Food Additives and Contaminants 21: 598-606.

Ukai, T., Yamamoto, Y. and Yamamoto, T., 1954. Studies on the poisonous substance from a strain of Penicillium (Hori-Yamamoto strain) II. Culture method of Hori-Yamamoto strain and chemical structure of its poisonous substance. Journal of the Pharmaceutical Society of Japan 74: 450-454.

Umezawa, M, Mizuhara, Y., Uekane, K. and Hagihara, M., 1947. A crystalline antibacterial substance from Penicillium leucopus and four other strains of Penicillium sp. and Aspergillus clavatus and its probable identity with patulin. Journal of Penicillin 1: 6-13.

Van Eijk, G.W., 1969. Isolation and identification of orsellinic acid and penicillic acid produced by Penicillium fennelliae Stolk. Antonie van Leeuwenhoek 35: 497-504.

Van Luijk, A., 1938. Antagonism between various micro-organisms and different species of the genus Pythium, parasitizing upon grasses and lucerne. Mededelingen Phytopathologisch Laboratorium, Baarn, Scholten 14: 43-89.

Vansteelandt, M., Kerzaon, I., Blanchet, E., Du Pont, T.R., Jouibert, Y., Frisvad, J.C., Pouchus, Y.F. and Grovel, O., 2012. Patulin and secondary metabolite production by marine-derived Penicillium strains. Fungal Biology 116: 954-961.

Varga, J., Due, M., Frisvad, J.C. and Samson, R.A., 2007a. Taxonomic revision of Aspergillus section Clavati based on molecular, morphological and physiological data. Studies in Mycology 59: 89-106.

Varga, J., Frisvad, J.C. and Samson, R.A., 2007b. Polyphasic taxonomy of Aspergillus section Candidi based on molecular, morphological and physiological data. Studies in Mycology 59: 75-88.

Varga, J., Frisvad, J.C. and Samson, R.A., 2011b. Two new aflatoxin producing species, and an overview of Aspergillus section Flavi. Studies in Mycology 69: 57-80.

Varga, J., Frisvad, J.C., Kocsubé, S., Brankovics, B., Tóth, B., Szigeti, G. and Samson, R.A., 2011a. New and revisited species in Aspergillus section Nigri. Studies in Mycology 69: 1-17.

Veselá, D. and Veselý, D., 1995. Determination of Penicillium species using the production of mycotoxins. In: Kubátová, A. and Prásil, K. (eds.) Present state, modern methods and perspectives in Penicillium study. Proceedings of the Penicillium seminar. June 9, 1994. Czech Scientific Society for Mycology Praha, Prague, Czech Republic, pp. 98-102.
Vesely, D. and Veselá, D., 1991. The use of chick-embryo for prediction of some embryotoxic effects of mycotoxins in mammals. Veterinary Medicine 36: 175-182.

Visagie, C.M., Houbraken, J., Frisvad, J.C., Hong, S.-B., Klaassen, C.H.W., Perrone, G., Seifert, K.A., Varga, J., Yaguchi, T. and Samson, R.A., 2014b. Identification and nomenclature of the genus Penicillium. Studies in Mycology 78: 343-371.

Visagie, C.M., Varga, J., Houbraken, J., Meijer, M., Kocsubé, S., Yilmaz, N., Fotedar, R., Seifert K.A., Frisvad, J.C. and Samson, R.A., 2014a. Ochratoxin production and taxonomy of the yellow aspergilli (Aspergillus section Circumdati). Studies in Mycology 78: 1-61.

Visagie, C.M., Yilmaz, N., Renaud, J.B., Sumarah, M.W., Hubka, V., Frisvad, J.C., Chen, A.J., Meijer, M. and Seifert, K.A., 2017. A survey of xerophilic Aspergillus from indoor environment, including descriptions of two new section Aspergillus species xerophilic species producing eurotium-like sexual states. MycoKeys 19: 1-30.

Vismer, H.F., Sydenham, E.W., Schlechter, M., Brown, N.L., Hocking, A.D., Rheeder, J.P. and Marasas, W.F.O., 1996. Patulin producing Penicillium species isolated from naturally infected apples in South Africa. South African Journal of Science 92: 530-534.

Wareing, P., Westly, A., Gibbs, J.A., Allotey, L.T. and Halm, M., 2001. Consumer preferences and fungal and mycotoxin contamination of dried cassava products from Ghana. International Journal of Food Science \& Technology 36: 1-10.

Welke, J.E., Hoeltz, M., Dottori, H.A. and Noll, I.B., 2011. Patulin accumulation in apples during storage by Penicillium expansum and Penicillium griseofulvum strains. Brazilian Journal of Microbiology 42: $172-180$

Wiesner, B.P., 1942. Bactericidal effect of Aspergillus clavatus. Nature 149: 356-357.

Wilson, D.M., 1976. Patulin and penicillic acid. Advances in Chemistry 149: 90-109.

Wirth, J. and Klosek, R., 1972. Fungi. Moniliales. Relationships in Penicillium aurantiovirens. Phytochemistry 11: 2615.

Wirth, J.C., Gilmore, T.E. and Noval, J.J., 1956. Penicillic acid, the antibiotic responsible for the activity of a culture filtrate of a strain of Penicillium martensii Biourge. Archives of Biochemistry and Biophysics 63: 452-453.

Wouters, M.F.A. and Speijers, G.J.A., 1996. Patulin. In: World Health Organisation (eds.) Toxicological evaluation of certain food additives and contaminants. WHO, Geneva, Switzerland, pp. 337-402.

Xie, F.-C., Liu, C.-L., Yang, X.-Z. and Chen, Y.-L., 2011. Isolation of main patulin-producing strains from storage pears and their ITS sequences analysis and identification. Food Fermentation in India 37: 54-57.

Yamaji, K., Fukushi, Y., Hashidoko, Y. and Tahara, S., 2005. Penicillium frequentans isolated from Picea glehnii seedling roots as a possible biological control agent against damping-off. Ecological Research 20: 103-107.

Yamamoto, T., 1954. Studies on the poison producing mold isolasted from dry malt. VII. Variation of patulin during culture of Penicillium urticae Bainier. Journal of the Pharmaceutical Society of Japan 76: 1377-1381.

Yamamoto, W., Yoshitani, K. and Maeda, M., 1955. Studies on the Penicillium and Fusarium rots of Chinese yam and their control. Science Reports of the Hyogo University of Agriculture 1: 69-79. 
Yang, J., Li, J., Jioang, Y., Duan, X., Qu, H., Yang, B., Chen, F. and Sivakumar, D., 2014. Natural occurrence, analysis and prevention of mycotoxins in fruits and their processed products. Critical Reviews in Food Science and Nutrition 54: 64-83.

Yassin, M.A., El-Samawaty, A.R., Bahkali, A., Moslem, M., Abd-Elsalam, K.A. and Hyde, K.D., 2010. Mycotoxin-producing fungi occurring in sorghum grains from Saudi Arabia. Fungal Diversity 44: 45-52.

Yeulet, S.E., Mantle, P.G., Rudge, M.S. and Greig, J.B., 1988. Nephrotoxicity of Penicillium aurantiogriseum, a possible factor in the etiology of balkan Endemic Nephropathy. Mycopathologia 102: 21-30.

Yin, G., Zhang, Y., Sheng, S., Hua, S.S.T., Yu, J., Bu, L., Pennerman, K.K., Huang, Q., Guo, A. and Bennett, J.W., 2017. Genome sequencing and analysis of the postharvest fungus Penicillium expansum R21. Genome Announcemetns 5: e01516-16.

Yu, J., Jurick, W.M., Cao, H., Yin, Y., Gaskins, V.L., Losada, L., Zafar, N., Kim, M., Bennett, J.W. and Nierman, W.C., 2014. Draft genomne sequence of Penicillium expansum strain R19, which causes postharvest decay of apple fruit. Genome Announcements 2: e00635-14.
Yu, K., Ren, B.AS., Wei, J.L., Chen, C.X., Sun, J.S., Song, F.H., Dai, H.Q. and Zhang, L.X., 2010. Verrucicinol and verrucosidinol acetate, two pyrone-type polyketides isolated from a marine derived fungus, Penicillium aurantiogriseum. Marine Drugs 8: 2744-2754.

Yun, H., Lim, S., Chung, J., Jo, C., Park, J., Kwon, J. and Kim, D., 2006. Isolation and characterization of Penicillium crustosum, a patulin producing fungus, from apples. Food Science and Biotechnology 15: 896-901.

Zhang, D., Yang, X., Kang, J.S., Choi, H.D. and Son, B.W., 2008. Chlorohydroaspyrones A and B, antibacterial aspyrone derivatives from the marine-derived Fungus Exophiala sp. Journal of Natural Products 71: 1458-1460.

Zheng, J., Xu, Z., Wang, Y., Kong, K., Liu, P. and Zhu, W., 2010. Cyclic tripeptides from the halotolerant fungus Aspergillus sclerotiorum PT06-1. Journal of Natural Products 73: 1133-1137. 